\title{
Framework conditions for Nordic district heating - Similarities and differences, and
} why Norway sticks out

\author{
Sandberg, Eli; Sneum, Daniel Møller; Trømborg, Erik
}

Published in:

Energy

Link to article, DOI:

10.1016/j.energy.2018.01.148

Publication date:

2018

Document Version

Peer reviewed version

Link back to DTU Orbit

Citation (APA):

Sandberg, E., Sneum, D. M., \& Trømborg, E. (2018). Framework conditions for Nordic district heating Similarities and differences, and why Norway sticks out. Energy, 149, 105-119.

https://doi.org/10.1016/j.energy.2018.01.148

\section{General rights}

Copyright and moral rights for the publications made accessible in the public portal are retained by the authors and/or other copyright owners and it is a condition of accessing publications that users recognise and abide by the legal requirements associated with these rights.

- Users may download and print one copy of any publication from the public portal for the purpose of private study or research.

- You may not further distribute the material or use it for any profit-making activity or commercial gain

- You may freely distribute the URL identifying the publication in the public portal 


\section{Accepted Manuscript}

Framework conditions for Nordic district heating similarities and differences, and why Norway sticks

Eli Sandberg, Daniel Moller Sneum, Erik Tromborg

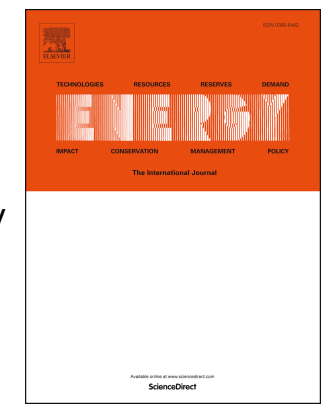

PII:

S0360-5442(18)30176-2

DOI:

10.1016/j.energy.2018.01.148

Reference: EGY 12260

To appear in: Energy

Received Date: 28 August 2017

Revised Date: 22 January 2018

Accepted Date: 27 January 2018

Please cite this article as: Sandberg E, Sneum DM, Tromborg E, Framework conditions for Nordic district heating similarities and differences, and why Norway sticks, Energy (2018), doi: 10.1016/ j.energy.2018.01.148.

This is a PDF file of an unedited manuscript that has been accepted for publication. As a service to our customers we are providing this early version of the manuscript. The manuscript will undergo copyediting, typesetting, and review of the resulting proof before it is published in its final form. Please note that during the production process errors may be discovered which could affect the content, and all legal disclaimers that apply to the journal pertain. 


\section{FRAMEWORK CONDITIONS FOR NORDIC DISTRICT HEATING}

Similarities and differences, and why Norway sticks out

\section{TABLE OF CONTENTS}

\section{Abstract}

Introduction

Method and data

Results

Discussion

Conclusions

Acknowledgments

Abbreviations

References

Table 1

Table 2

Table 3

Table 4

Table 5

Table 6

Table 7

Abstract

The district heating $(\mathrm{DH})$ sectors differ considerably among the Nordic countries: $\mathrm{DH}$ is an important contributor to heat supply in Denmark, Finland and Sweden, but in Norway it plays only a minor role. In this study, we compare historical, economic, jurisdictional, political and geographical framework conditions for $\mathrm{DH}$ and assess their impacts on the development of $\mathrm{DH}$ in the Nordic region. $\mathrm{DH}$ is subject to national and municipal regulations, with tax and subsidy schemes that are complex and vary between the countries. The total fuel prices induce differences in fuel distribution. Electricity is competitive, both in $\mathrm{DH}$ and individual heating in Norway. This study further suggests, by comparing 
the impacts and implications of differences in cost components in a model plant, that differences in profitability is currently small between the Nordic countries. However, historical and geographical factors, such as local commitment and differences in infrastructure, constitute the major difference in the penetration of DH. Adaptability, in terms of fuel flexibility, is important for the industry's survivability and electricity prices are crucial for the development of DH. Energy efficiency measures and competition from residential heat pumps are the industry's largest challenges.

Keywords: District heating, Energy policy, Framework conditions, Nordic

\section{Introduction}

District heating $(\mathrm{DH})$ is defined as distribution of thermal energy in the form of steam or hot water from a central source of production through a network to multiple buildings or sites [1]. DH is used for space heating and tap water systems; hence, a water-borne heat distribution system is prerequisite in buildings served by $\mathrm{DH}$. DH generation comes from a variety of fuels, such as waste incineration, waste heat, wood chips, coal, gas, oil, or electricity in electric boilers (EBs) or heat pumps (HPs) [2]. Whereas heat-only (HO) plants solely rely on boilers or HPs to provide heat for the $\mathrm{DH}$ network, combined heat and power (CHP) plants also produce electricity, which increases the efficiency compared to boiler-based plants.

There are many advantages of $\mathrm{DH}$. DH plants can utilize local energy sources and a variety of fuels, including some that otherwise would be wasted, so it increases the efficiency of energy production [3]. A positive external effect of utilizing domestic fuels is that it stimulates economic growth locally [4]. Due to fuel flexibility, DH has served, since the oil crisis in 1974, as a means to reduce oil dependency, and since the 1990s, as a means of reducing greenhouse gas emissions [5].

In reviewing previous studies in this field, we found no comparative studies of framework conditions for DH in the Nordic countries and no studies attempting to explain why DH markets took different directions. A. Lake et al. [6] reviewed literature concerning DH, and included historic, economic and policy factors, but for $\mathrm{DH}$ in general and for predicting its future role. M. Wissner [7] described regulation of $\mathrm{DH}$ in general, with a focus on price regulation. S. Akhtari et al. [8] reviewed previous work on the economic feasibility of biofuel-based $\mathrm{DH}$, but they were also not country-specific. A. Colmenar-Santos et al. [5] presented the status and future prospects of DH in EU-28, with a focus on CHP. A few studies have compared Nordic countries in different aspects. R. Fazeli et al. [9] compared energy demand for space heating in the Nordic countries, and presented the history of individual heating $(\mathrm{IH})$ in each Nordic country, but with the aim of revealing the best method for estimating fuel demand. A. Aslani et al. [10] compared policy frameworks for renewable energy, including DH, in the Nordic region. Apart from A. Chittum and P. Østergaard [11], who presented policies for DH in Denmark, most studies have looked at specific framework conditions and evaluated the effect of these, and mostly for one specific country or specific affected actors. For example, T. Unger and E. Ahlgren [12] evaluated the impact of green certificates on Nordic countries; A. Chittum and P. Østergaard [11] evaluated heat planning in Denmark; and H. Sjølie et al. [13] assessed policies for promoting bio-energy in Norway. Quite a few studies have included a historic presentation of the development of DH. S. Werner [14], P. Westin and F. Lagergren [15], L. di Lucia and K. Ericsson et al. [3] and D. Magnusson [16] presented the development of DH in Sweden; B. Sovacool [17] did the same for Denmark; M. Forbord et al. [18] and E. Trømborg et al. [19] for Norway; and S. Helynen [20] for Finland, but the latter three with a focus on bio-energy. Some studies also present the status of 
DH at the time of their writing: A. Gebremedhin [21] presented the DH picture in Norway; S. Paiho and F. Reda [22] in Finland; S. Werner [14] in Sweden and P. Østergaard and A. Andersen [23] in Denmark.

The objectives of this study are to describe both the development and the current position of DH in the Nordic countries, analyse the differences in costs and revenues affecting the profitability of investment in and operation of $\mathrm{DH}$, and assess the economic and operational impacts of the differences in costs and revenues. Finally, we aim to discuss the impacts of other framework conditions for $\mathrm{DH}$ and some policy implications for the development of the $\mathrm{DH}$ sector.

When considering the framework conditions for $\mathrm{DH}$, it is relevant to bring in the consumer side, and compare $\mathrm{DH}$ to alternative heating systems. We thereby compare the heat costs of different options for $\mathrm{IH}$ in the different countries, to be able to discuss the competitiveness of $\mathrm{DH}$ in the market for heat.

This study aims to identify the framework conditions that have been and are most significant for the past, current and future development of Nordic DH. Future developments can benefit from this view of the past and present, firstly due to the large share of heat demand covered by $\mathrm{DH}$, secondly for the role of $\mathrm{DH}$ in the transition to energy systems increasingly supplied by renewable energy sources (RES), and thirdly due to the contribution of DH to social welfare.

Chapter 2 presents the data collection, the categorization of the data and the preconditions for the analysis of the quantitative data in this study. In chapter 3, we first present the historical development and status of Nordic $\mathrm{DH}$, then go on to describe its current framework conditions. The third part of chapter 3 presents the economic framework conditions, which Nordic DH systems are facing. In the fourth part of chapter 3, the economic framework conditions are included in a presentation of a model plant. The fifth and last part of chapter three presents a study of the costs of different alternatives for $\mathrm{IH}$. In chapter 4 , we discuss the impacts of economic and other framework conditions on Nordic DH. Additionally, we discuss the further development of Nordic DH and suggest implications of this study. In chapter 5 , we present conclusions of the study.

\section{Method and data}

\section{Data collection and categorization of the framework conditions}

This study is based on a qualitative review of framework conditions for $\mathrm{DH}$ in the Nordic countries and a quantitative data collection of economic parameters, such as fuel prices, DH prices, labour costs, taxes and subsidies. The qualitative approach has been applied to identify, structure and explain the effects of the different framework conditions. The quantitative approach is conducted in Excel and aims at quantifying the effects on the model plant's profitability by applying the different countries' fuel prices and different country's revenues and costs such as heat prices, fuel prices and tax schemes. The framework conditions were collected through an extensive review of national regulations, public reports and statistics, through desk research and correspondence with national parties and authorities in the Nordic countries.

We use the 2015 average DH price to compare the profitability of the model plant in the different countries, and the 2016 average $\mathrm{DH}$ price to compare alternatives for $\mathrm{IH}$ with $\mathrm{DH}$. The average $\mathrm{DH}$ prices come from the countries' official statistics. Enova provides information about the investment 
subsidy for DH plants based on RES [24]. The wood chip price is taken from the industry association in Denmark, the official statistics bureau in Finland, and the national energy authorities in Norway and Sweden [25][26][27][28]. The fuel oil price is assumed to be homogeneous for all countries, and is taken from the European commission [29]. The taxes are taken from the national tax or customs authorities and excise legislation [30][31][32][33][34]. The fuel cost for IH is derived from private fuel traders, while taxes come from each country's tax authorities. The labour cost levels come from Eurostat's annual labour cost data [35], and the exchange rate used is an annual average of the exchange rates provided by the national banks [36][37][38].

The historical factors brought up in this study are a compilation from reviewed literature, public reports and releases by industry associations. The status for the Nordic countries combined, as presented here, is a result of data collection from public statistics, industry associations and national energy authorities.

Many different framework conditions affect the DH sector, slightly or significantly, depending on the market structure. The framework conditions may affect different components of the DH system, such as fuel, technology or DH consumers. Some framework conditions may have a positive or negative impact on the operation of DH plants, while others affect investment decisions. Some of the framework conditions are specific to the DH sector, while other framework conditions affect the $\mathrm{DH}$ sector indirectly by being means for other aims. The different framework conditions may be implemented at a local level, such as the electricity grid tariffs or mandatory connection; nationally, such as tax or subsidy schemes; bilaterally, such as the green certificate scheme; or at an international level, such as EU legislation and commitment to reduction of $\mathrm{CO} 2$ emissions. The framework conditions may be jurisdictional; a political priority; an external effect of instruments for other targets; or factors out of the DH enterprises' control, such as geographical factors.

The focus in this study is on identifying framework conditions that affect investment decisions and the operation of existing DH plants. We separate the framework conditions into three main categories: historical framework conditions, economic framework conditions, and other framework conditions that affect the DH sector. Historical framework conditions are framework conditions that have influenced the development of the DH sectors in the Nordic countries. Economic framework conditions include financial framework conditions, such as taxes and subsidies, and quantifiable external framework conditions, such as fuel costs (including electricity and natural gas grid tariffs) and labour costs. The category "other framework conditions" includes framework conditions on the consumer side and framework conditions whose impact on DH we cannot as easily measure; it is thus analysed qualitatively. Table 1 presents a selection of framework conditions that are quantifiable or mentioned in the literature as drivers or barriers for $\mathrm{DH}$.

\section{Preconditions}

For the model plant, investment costs are used from M. Rosenberg [39], while recognizing that other sources have different cost estimates [27][40][41][42]. We have thus assumed that the costs presented by Rosenberg are not only representative for this type of plant all over Norway, but also for the other Nordic countries. We have assumed that the technologies, variable operation and maintenance (O\&M) costs and costs of material are the same throughout the Nordic countries, but we have adjusted for differences in labour cost levels for fixed O\&M and the investment costs that are dependent on labour costs, such as administration costs, installation costs, construction costs and engineering. The model plant contains one base-load boiler (wood chips) and one peak-load boiler (fuel oil). Current deployment of DH throughout the Nordics covers most major cities. Thus, new capacity is more likely to be on a smaller scale, represented by our model plant. Additionally, 
there are only a few large plants in Norway and Denmark. Figure 8 shows the distribution of plant size in Nordic DH. We assume that the DH plant is financing the heating centre, the DH network and the heat exchangers for the customers, but the consumers are covering the cost of pipes from the heat exchanger to the buildings and the installation and engineering costs of the DH system beyond the heat exchanger. We further assume that the $\mathrm{DH}$ producers are subject to quota obligations, as there may be differences in policies for $\mathrm{DH}$ generators that are subject to quotas and those which are not. The input data for fuel costs, taxes and subsidies are country specific and differ among the Nordic countries. Technical specifications of the model plant are listed in the table below.

The assumptions for different IH alternatives are based on [34][40][43][44]. The costs of installation are adjusted for differences in labour cost levels. Material costs are assumed to be homogeneous for the Nordic countries, but the fuel costs, taxes and subsidies are country specific. The electricity price depends on the household's total electricity consumption. We assume an electricity consumption for non-heating purposes of $4 \mathrm{MWh}$ [45]. The total electricity consumption for heating is the sum of electricity used as fuel for HPs and direct electric heating, electricity used to cover the heat consumption that the unit does not cover, including hot tap water, and auxiliary electricity consumption. We have assumed that the Air-to-air (A2A) HP and the firewood stove cover $60 \%$ of the demand for space heating, with the rest of the demand for space heating to be covered by direct electric heating, and that electric heaters cover the demand for hot water. Additionally, due to a minimum load of oil and pellet boilers, we assume that these boilers are not used during summer time, such that direct electric heating cover the heat demand during summer. Electricity consumption that covers the heat demand that the unit does not cover, is included in auxiliary electricity consumption. The auxiliary electricity consumption is thus higher for these $\mathrm{IH}$ technologies. Heating options that include a hydronic system also cover the demand for hot tap water. Table 3 shows the technical specifications for different IH alternatives.

Figure 1 presents a DH system and its components, and shows examples of framework conditions that the producers and consumers are facing. The figure also presents the delineation of this study, by specifying the model plant and a standard consumer.

\section{Results}

\section{The development and status of Nordic district heating}

Denmark was the first of the Nordic countries to develop $\mathrm{DH}$, and had several $\mathrm{DH}$ plants in the larger cities in the 1920's [46]. Sweden and Finland established DH just after World War II; the post-war electricity shortage and lack of heating options were the main reasons for the first steps in developing DH in these countries [47][48]. In Norway, however, DH was non-existent before the 1980 's. The many mountains, waterfalls and uninhabited acreage have given Norwegians a natural basis for hydropower with reservoirs. A massive development of hydropower took place in Norway from 1950 to 1980, and laid the groundwork for an electricity-based energy resource for heating. The need for alternative energy sources was first recognized when hydropower development struck natural sites with high recreational value in the late 70's [49]. The reason for the establishment of the first individual plants in all the Nordic countries was to make use of municipal waste. Later, the expansion in Denmark, Finland and Sweden was justified by exploiting the waste heat from electricity production. Even though coproduction was the main argument for DH in Sweden, the development met strong opposition from the electricity producers. Sweden has a large share of 
hydro and nuclear power and low electricity prices, so a lack of incentives for the electricity producers caused slow development of CHP in Sweden. DH in Sweden, however, had great support from municipalities and the local population, due to the housing shortage in the 60 's as many new municipal and private buildings were connected to DH [14]. Economic growth in Denmark and the strong cooperative movement founded on the common practice of agricultural cooperatives can also explain the expansion of DH in Denmark from the 50's, in addition to low oil prices [46]. Low oil prices can partly explain the development of Finnish $\mathrm{DH}$ from the 50's. In addition, the Finnish government promoted DH through subsidies and beneficial loans. The oil crisis in 1974 gave a fright to the Nordic DH sectors, but fuel flexibility and the sector's adaptability led the industry through the crisis. The Finnish government had already, in the 60's, developed a subsidy scheme to promote domestic fuels in the DH sector, and many wood-chip fired CHP plants were up and running by then.

When the oil crisis came, DH actually grew in importance; the energy sector took notice of the energy-saving benefits, and DH became a measure to reduce the dependency on fuel imports. The use of peat and wood chips in Finland increased from 1974, and the development of Finnish DH had a boost into the 90 's. The growth in the 80 's was mostly due to the role of municipalities and their support of cogeneration [48]. The post-oil-crisis energy policy of reducing dependence on oil created a major expansion phase for Swedish DH in the 80's [47]. Danish DH was largely oil dependent when the oil crisis struck and had to go through major restructuring. The focus was mainly on increasing cogeneration and converting to coal and waste as fuels. Danish $\mathrm{DH}$ was better equipped when the second oil crisis struck, but it triggered a further focus on reducing oil dependency through increasing the use of coal, straw and municipal waste. Danish DH met challenges again as global warming appeared on the agenda in the mid 80's and energy taxes increased the prices of coal and heating oil. Also, the Danish DH sector has been forced to pay part of the bill for costly natural gas extraction from the North Sea and this has possibly been an obstacle for Danish DH. These elements combined to prompt an increase in the proportion of cogeneration, and increased use of wood chips, municipal waste, biogas and solar heating in the 90's. Despite the obstacles, DH supplies a similar amount of energy as the electricity sector in Denmark. The main reasons are a business model based on the break-even principle, and the Danish mindset of sharing: in addition, a planned expansion of the energy system has been central, and $\mathrm{DH}$ has been a central part of this planning. Moreover, Denmark shares adaptability and fuel flexibility with other Nordic DH sectors [46].

In Sweden, however, the issue of global warming is another growth factor for Swedish DH because $\mathrm{DH}$ plays a role in decreasing climate gas emissions. Sweden employs a large share of biofuel in the generation of electricity and heat, and the Swedish government introduced investment support schemes for $\mathrm{DH}$ and conversion from direct electric heating in the 90's. In addition, discussions around closing down nuclear power plants in the late 90's promoted DH as a means of reducing Sweden's dependence on electricity [50].

The industry association for heating, ventilation and sanitary engineering initiated the formation of a $\mathrm{DH}$ association in Norway. In the other Nordic countries, the initiative came from the energy industry. Today, however, many of the power companies that previously relied on hydropower have become major suppliers of DH in Norway [49].

Whereas connection points are increasing, DH production is trending downwards in Denmark, Finland and Sweden. Even though production is still increasing in Norway, Norway does not seem to catch up with its neighbours. The Norwegian DH sector is characterized by densification; there are few new plants built, but existing plants are expanding [51]. Figure 2 shows the development of delivered DH in the Nordic countries. 
By the mid 90's, DH was a well-established form of heating in urban areas in Finland, Sweden and Denmark. In 2013, DH served more than 50\% of the population in Denmark, Finland and Sweden, while in Norway it reached only $1 \%$. The DH consumption per capita in Denmark, Finland and Sweden is more than five times higher than in Norway. In comparison, Norway's electricity consumption per capita is more than $50 \%$ higher than in Finland and Sweden, and four times higher than in Denmark [52]. Norwegian households use much more electricity for heating than the other Nordic countries; only 15\% of households had a hydronic system installed in 2012 [53][54]. The number is, however, increasing: hydronic systems are more common in new buildings than old and there are more apartments than detached houses with a water-borne system installed. Figure 3 below shows the share of energy sources supplying residential heating in the Nordic countries. The renewable share in electricity consumption is not known, but the renewable share in electricity generation in 2016 was 62, 44, 98 and 62 \% in Denmark, Finland, Norway and Sweden respectively. Norway and Sweden are net exporters of electricity. Finland mostly imports electricity from Sweden [52][55]. And Denmark from Sweden and Norway [56].

Norway and Sweden produce less power in their DH systems than Denmark and Finland. In 2013, the CHP share of electricity production in Denmark, Finland, Norway and Sweden was 66, 34, 0.5 and 9\% respectively, and the CHP share of $\mathrm{DH}$ production was 73, 73, 1.5 and $41 \%$ [57]. The share of biomass in heat production in Nordic DH has increased since the beginning of this century in all four countries, while the fossil share is decreasing. Denmark and Finland still have a large fossil fuel share in their $\mathrm{DH}$ production, of 40 to $50 \%$, while Sweden has by far the largest biomass share, of about $60 \%$ [58][59][60]. Municipal waste is the most used fuel in Norway; in 2016, nearly half of the heat production came from waste incineration plants [61]. Figure 4 shows the decreased use of fossil fuels for DH generation in the Nordic countries since the year 2000. The fossil fuels are mostly displaced by wood fuels. Figure 5 displays the fuel composition in Nordic DH generation in 2015.

The share of heat production using electricity as fuel is higher in Norway than in the other Nordic countries. Figure 6 shows the power-to-heat $(\mathrm{P} 2 \mathrm{H})$ share of total net $\mathrm{DH}$ generation in the Nordic countries.

Norway also stands out in that the service sector represents the largest consumer group, while the largest group of consumers in the other Nordic countries is made up of households. Figure 7 presents the consumer distribution in Nordic DH.

Accumulator tanks for daily storage are common in the other Nordic countries, but are only installed in a few DH plants in Norway [62]. The Nordic DH sectors all have large plants that significantly increase the average amount of delivered heat per DH enterprise. Compared to Denmark and Norway, Sweden and Finland have very large plants, and in Finland, there are few DH companies compared to the production level. In Denmark and Norway, most plants are relatively small, and Denmark has a large number of companies compared to the other Nordic countries. Figure 8 shows the distribution of $\mathrm{DH}$ generation between the DH companies in the Nordic countries.

\section{Framework conditions for Nordic district heating}

The electricity and $\mathrm{DH}$ sectors are subject to rather different types of regulation and markets. Electricity is traded in an integrated, common European power market, which is managed by common cross-border regulatory framework conditions. EU regulations mention $\mathrm{DH}$ in several directives, of which the most important is the requirement of an assessment of CHP and efficient DH in energy planning [63]. However, since the EU legislation is common to all Nordic countries, these 
framework conditions are left out of this analysis. DH is mostly regulated nationally and down to the municipal level. Denmark and Sweden have their own jurisdictional framework for the DH sector [64][65]. In Norway, the Energy Act incorporates DH [66]. In Finland, the DH sector is regulated to a greater extent by many different laws. The broad set of regulations is especially fostered by the wide variety of fuels and technologies that characterizes DH. Some of the regulatory framework conditions affect the use of various fuels, such as electricity tax and energy tax on fossil fuels. Certain instruments affect specific technologies, such as investment subsidies for renewable heat.

The implementation of instruments may vary, based on whether it is electricity or heat that is produced and whether the producers are subject to carbon quotas or not. Denmark, Norway and Sweden have different CO2-taxes for quota-regulated producers and firms with non-quota obligations. Most of the regulatory framework conditions aim to reduce $\mathrm{CO} 2$-emissions, reduce dependence on imported fossil fuels, or reduce dependence on direct electric heating, and thereby increase the security of supply.

The framework conditions may apply at different levels. Some of the framework conditions are defined by EU legislation and most of the jurisdictional and financial framework conditions apply to all DH companies within each country. However, some of the framework conditions may vary even locally. The municipalities decide mandatory connection, and the local grid operators set the electrical network tariffs.

$\mathrm{DH}$ is a long-term and capital-intensive investment and is often considered a natural monopoly [15][67][68]. Economic theory predicts that unregulated natural monopolies adapt to a lower production level than socially desired [68]. To ensure penetration of $\mathrm{DH}$, all the Nordic countries have offered investment support, beneficial loans and/or mandatory connection in the development phase or transition phases [20][69]. The municipalities in Denmark, Finland and Norway are allowed to impose mandatory connection to $\mathrm{DH}$ for new buildings, and in Denmark existing buildings may also be affected [70]. Denmark has a statutory heat plan which states that the municipalities, in collaboration with utilities and other stakeholders, are required to formulate a heat plan for the local heat supply [71].

There are different reasons for imposing regulations that may be considered barriers for DH producers. Unregulated monopolies may be tempted to offer excessively high prices compared to what is socially optimal [68]. This is, in many cases, taken care of through public ownership or zeroprofit constraints. Consumers in Denmark are protected from monopoly pricing by a profit cap for $\mathrm{DH}$ producers, forcing producers to set the $\mathrm{DH}$ price such that only the necessary costs are covered [72]. In Norway, the DH price cannot exceed the total electricity price if connection to $\mathrm{DH}$ is mandatory for the given consumer [73][74][75]. In Finland and Sweden, competition rules apply. In order to increase the competition and lower the DH price, third party access applies in Norway [76] and Sweden [77]. In addition to having the characteristics of a natural monopoly, DH has a negative externality of production in the form of $\mathrm{CO} 2$-emissions; thus, $\mathrm{DH}$ production based on fossil fuels is affected by climate policies.

Some of the most influential current economic and regulatory framework conditions in the Nordic countries are presented in Table 4. Sweden stands out by having the largest share of private ownership and the least direct public regulation of the current $\mathrm{DH}$ sector.

Considering geographical factors, Norway has a lower proportion of the population living in cities, a generally lower population density and a higher proportion of people living in detached houses 
compared to the other Nordic countries [78][79]. Denmark has a relative scarcity of forest resources compared to the other Nordic countries [9].

\section{Economic framework conditions}

Economic framework conditions are quantifiable framework conditions that affect the profitability of $\mathrm{DH}$ plants and thus the operation of, or investment in, DH plants. Table 5 below presents the average $\mathrm{DH}$ prices used as input for the model plant and to compare to options for $\mathrm{IH}$ for households.

$\mathrm{DH}$ plants with a high share of RES are eligible for investment support in Norway. Here, Enova's investment subsidy may amount to $50 \%$ of the investment costs [24]. Enova also offer subsidies for IH options. In 2017-prices liquid-to-water (L2W) HP may get an investment support of e3270, air-towater (A2W) HP e2180 [80], biomass boiler e2720 [81] and installation of a water-borne system e1090 [82]. Installation of a water-borne system will increase the investment costs by approximately $50 € / \mathrm{MWh}$ [83], depending on the labour cost levels. In Sweden, households may be eligible for a $30 \%$ deduction of the labour costs of installing different IH options, including DH [84].

All the Nordic countries have tax exemptions for biofuels. Sweden has higher taxes on fossil fuels than the other Nordic countries. Norwegian DH producers face considerably lower electricity prices than the other Nordic countries, due to a considerably reduced electricity tax [85] and because flexible grid tariffs are common for larger DSOs in Norway: flexible grid tariffs are a reduction in the load demand component of the grid tariffs for devices, such as EBs, that can be disconnected at short notice. This tariff is also seen in Sweden, but it is not common [86][87]. In Denmark, taxes on fuels used for heating, both for use in $\mathrm{DH}$ and for other consumers, can be partially refunded, making heat production costs lower than the general energy cost in Denmark [88]. All Nordic countries have exemptions in the tax system for DH producers. In Denmark, for example, the basis of the tax refund is the amount produced, while the initial tax payment is based on the production factors supplied. Thus, there is no uniform approach among the countries. Table 6 shows fuel price components of a selection of fuels for DH producers in the Nordic countries in calorific value and for the year 2015. The fuel oil and wood chip prices are used as inputs for the model plant.

Fuel cost components of $\mathrm{IH}$ options for the year 2016 are presented in table 7 below, together with the sources of the information. The electricity costs vary with the total electricity consumption. The numbers in this table present the electricity prices for an annual electricity consumption above 15 MWh. These prices are used as inputs for modelling the costs of different IH alternatives to compare it with $\mathrm{DH}$.

Norway has considerably higher labour cost levels compared to other Nordic countries. The labour costs for the three industry classes "construction", "engineering" and "electricity, steam and hot water supply" are up to $30 \%$ higher in Norway than in Finland, which has the lowest labour cost level in the Nordic countries [35]. Labour costs account for about 30\% of investment costs in pipelines, which are very labour intensive due to excavation work [39].

\section{Model plant}

In this section, profitability of the model plant are presented in two ways. Firstly as a calculation of potential annual profit of the plant without the DH network and consumer centrals, and using the 
national average DH price. Second, we present the annual costs of the model plant, including the DH network and consumer centrals. The realization of both operation and investment of the model plant is economically feasible in all the Nordic countries. The pre-tax net profit (the per MWh average DH price subtracted the total annual costs of the DH plant) is highest in Denmark and lowest in Sweden. The DH plant in Denmark can invest in 10 consumer centrals and a $14 \mathrm{~km}$ pipeline and still break even. The DH plant in Sweden can invest in 10 consumer centrals and an $8 \mathrm{~km}$ pipeline and still recover its investments. If the Norwegian model plant is eligible for an investment subsidy, the Norwegian model plant has the highest net profit, and the break-even length of the pipeline increases from 11 to $15 \mathrm{~km}$. Figure 9 represents the profitability of the model plant without the DH network and consumer centrals.

Investment costs in infrastructure and fuel costs are the largest cost components. Labour costs account for about $2 / 3$ of the O\&M costs and about $30 \%$ of investment costs in pipelines. The relatively higher labour costs in Norway makes the total annual costs slightly higher in Norway than in Sweden and Finland. The labour costs are lowest in Finland, making the total annual costs of this plant lowest in Finland. The relative lower DH price, however, makes the profit of the Finnish DH plant lower. Sweden has higher taxes on fossil fuels, which makes the $\mathrm{CO} 2$ tax component relatively higher in Sweden. The relative scarcity of forest resources in Denmark makes the costs of wood fuels higher in Denmark. The high fuel costs makes the total annual costs higher in Denmark than in the other Nordic countries, but the relatively higher DH price makes the profitability higher. The Norwegian investment subsidy may amount to $50 \%$ of the investment costs, making this plant in Norway the most profitable in the four countries. Figure 10 shows the total annual cost components of the model plant with assumed pipeline of $15 \mathrm{~km}$ and 10 consumer centrals.

\section{The competitiveness of district heating}

By comparing the costs of different heating options for a standard house in the Nordic countries, and assuming that a water-borne system is in place, we find that wood pellet boilers have lower heating costs than DH in Norway and Sweden. In Denmark, natural gas boilers have slightly lower heating costs than DH. HPs are more competitive to DH in Norway than in the other Nordic countries. Electricity is relatively more expensive in Denmark than in the other Nordic countries, making the cost of HPs and heating options that requires auxiliary electricity consumption more than $50 \%$ higher than the heating costs of $\mathrm{DH}$. Wood fuels are also relatively more expensive in Denmark than in the other Nordic countries, making wood stoves and wood pellet boilers relatively more expensive in Denmark than in Finland, Norway and Denmark. In Norway, electricity is relatively less expensive for households with high consumption levels, while the total electricity costs in Finland are relatively less expensive for households with a low electricity consumption. Oil boilers, wood stoves with direct electric heating and direct electric heating are not competitive to $\mathrm{DH}$ in any of the Nordic countries.

Removing the assumption that a water-borne system is in place, increases the costs of heating options that requires a hydronic system by $30-40 \%$. This makes all heating options that does not require a hydronic system competitive to DH in Norway. A2A HPs becomes competitive to DH in Finland, Norway and Sweden, and wood stoves with supplementary direct electric heating competitive to DH in Norway and Sweden. Figure 11 shows the total heating costs of $\mathrm{IH}$ in the Nordic countries when assume a water-borne system already in place. 


\section{Discussion}

\section{Economic framework conditions}

$\mathrm{DH}$ is a capital-intensive long-term investment on both the producer and consumer side [89]. The investment cost of the $\mathrm{DH}$ network constitutes $40 \%$ of the total annual costs in Norway for the model plant. Labour costs constitute $50 \%$ of the investment costs in the $\mathrm{DH}$ grid. Due to relatively larger labour costs in Norway, the annual capital costs are up to $20 \%$ higher than for the other Nordic countries. This is however not the case for DH plants eligible for an investment subsidy, since the impact of the subsidy on the DH plant's profitability outperforms the labour cost effect.

The investment subsidy has been crucial for the development of DH in Norway [90][91][13][18]. The support schemes for renewable heat introduced in Sweden and Finland in the 70's have also proven efficient drivers for increasing the share of RES in Swedish and Finnish DH [20][92]. For the model plant in this study, the Norwegian investment subsidy makes the difference between having the highest or lowest pre-tax net profit among the Nordic countries. The subsidy also allows investment in three additional kilometres of pipeline, while still breaking even. The profitability of this plant, however, is quite low, and the length of the pipeline to break even is much shorter than the average length of the pipelines in the Nordic countries [57]. This, in addition to the markets being saturated, may explain densification, rather than new investments in Nordic DH. The longevity of the network may however vary. A higher technical lifetime makes the annual capital costs of the grid investment lower. The cost of heat production varies with the different generation technologies [93], and waste incineration plants seem to have the lowest production costs compared to other DH technologies [94]. The profitability of waste incineration plants may thus be higher than for the model plant in this study. Additionally, economies of scale will give higher profitability for larger DH plants [95]. Exploring the sensitivity of scale, we experimentally increase the scale of the biomass boiler from the analysed $10 \mathrm{MW}$ to $30 \mathrm{MW}$. This results in a decrease of the total annual costs of the biomass boiler by $30 \%$. Increasing the scale of the heat exchangers and the peak load boilers will increase the total annual costs by proportionally less than the increase of scale. The heat demand is dependent on the outdoor temperature. Lower outdoor temperatures or higher desired indoor temperatures will increase the heat demand and the electricity price, and the competitiveness of DH would increase [96]. The countries vary in temperature and heat demand. This is not reflected in the analysis. In addition, the efficiency of air-based HPs will probably be higher in Denmark, due to higher air temperatures.

This study shows that the margins on the effect of differences in profitability of DH generation cannot explain the differences in penetration of $\mathrm{DH}$ in the Nordic countries. Relatively higher labour costs in Norway make investment costs in DH higher than in the other Nordic countries, but the investment subsidy outperforms this effect. Relatively higher fuel prices in Denmark, relatively lower $\mathrm{DH}$ prices in Finland, and relatively higher taxes in Sweden equalize the model plant's profitability in the different Nordic DH markets. Differences in fuel prices, including taxes, may however explain the differences in fuel composition in Nordic DH. The relative scarcity of biomass in Denmark makes the price of biofuels relatively higher. Norway has lower costs for the utilization of P2H technologies, and Sweden has high taxes on fossil fuels compared to the other Nordic countries. A study from Sweden supports this, by concluding that the growth of the use of biomass in $\mathrm{DH}$ has been stronger in Sweden, compared to Finland, because high taxes on fossil fuels have given a strong price incentive to increase the renewable share [16]. 


\section{Other framework conditions}

This study shows that one explanation for the low penetration of DH in Norway may be on the demand side. HPs are one of the largest competitors to DH [58][97]. A study from Sweden shows that HPs and pellet burners are competitive in residential urban areas in Sweden [89]. We found that, when we relax the assumption that a water-borne system is installed, several $\mathrm{IH}$ options become competitive to DH in Norway. Capital costs of construction are project specific and vary with local conditions [98][7], and the installation costs of water-borne systems in Norway may also be higher than in the other Nordic countries. This may contribute to explaining the low penetration of DH in Norway. Trømborg et al.[19] claim that high investment costs due to the low prevalence of water-borne heating systems in buildings, combined with relatively low electricity prices, are the main reasons for the differences in the market penetration of DH in Norway relative to other Nordic countries. Several studies point out that the heat density is important for the development of DH [99][100]. The relatively more distributed housing in Norway is also mentioned in the literature as one of the main reasons for the differences in the size of the $\mathrm{DH}$ sectors in the Nordic countries [9][101]. One factor, not considered here, is that the electricity price is often higher during the heating season, which is an advantage for DH [102]. Additionally, people may have additional preferences for $\mathrm{IH}$ options other than the price, such as aesthetic and recreational value.

The historical review suggests that the timing of measures to promote $\mathrm{DH}$ may have great importance and the regulatory framework conditions have a greater impact in the development phase. This is due to lock-in effects [7]. Investments in DH systems and water-borne systems are cost intensive and substitution of fuels for $\mathrm{DH}$ generation and $\mathrm{IH}$ option is possible only for certain fuel configurations [103]. Other obstacles mentioned in the literature are habits that are hard to break for instance, that Norwegian households are used to electric appliances - and knowledge from experience, which amplifies the lock-in effect [90]. Despite this, the DH sector has a strong survivability because of the ability to adapt to changes in energy policy by changing the fuel composition. The Nordic DH sector has survived through the political focus on reducing oil dependency in the 70's and 80's, and reducing climate gas emissions in the 90's [20]: fuel flexibility is a comparative advantage of the DH sector [17]. When the other Nordic countries focused on developing the $\mathrm{DH}$ sector, Norway put its efforts into electricity-based technologies [9]. Denmark does not have the resources to utilize hydropower, while Finland and Sweden introduced nuclear power. Local commitment and local governments have played a significant role in this, in terms of a positive attitude towards the development of DH [67][104]. Chittum and Østergaard [11] emphasized the importance of local authorities and energy planning in Danish DH development, and Ericsson et al.[16] mentions local commitment as a strong driver for the development of Finnish and Swedish DH. Local energy plans could contribute to cost efficiency, in that local knowledge may be significant in decision processes. Such arrangements are also predictable in the long term, despite political shifts. Hawkey and Webb [105] argue that the growth basis for DH is greater if national and local governments, as well as the energy companies and other business interests cooperate, for instance within waste incineration and the utilization of waste heat. Licensing and planning also create long-term commitment and predictability. 
Due to obligations for reducing climate gas emissions, we will see the trend of an increasing share for RES in DH. This increase will increasingly consist of solar technologies, due to decreasing investment prices and increasing costs of biofuel as the biomass share increases [69]. The continuous focus on energy efficiency in buildings will continue reducing residential and service sector heat demand [106]. For the survival of the DH sector, a broader application of heat delivery, as in washing machines, dishwashers and for industrial processes may be among the solutions [107]. It is also likely that the need for district cooling will continue to increase [47]. Prosumers may be a new actor on the DH markets [22]. The competition from HPs will continue to be strong. Stable low electricity prices, even during winter, strengthen the position of HPs [108][109]. Werner concludes that we will see DH in dense urban areas and local HP in suburban and rural areas [14]. However, studies from Sweden, Finland and Norway show low financial performance of investment in small and medium scale DH, even for mature technologies [110][111][112][113][114].

\section{Implications}

Local variations in investment costs and differences in technical configuration make it hard to generalize based on a comparison of model plants. A collection of investment costs in the Nordic countries would strengthen the assessment of economic framework conditions for model plants and costs for $\mathrm{IH}$. To strengthen the analysis of other political and regulatory framework conditions, a ranking of the importance of these could be conducted through surveys. The effects of other political targets, like reducing climate gas emissions, reducing the dependence on electricity, increasing the security of supply, increasing energy system flexibility and strengthening local businesses are not considered here, although many of the framework conditions mentioned in this study are affected by these targets: the framework conditions may overlap or contradict the different targets.

Tax rules or tax exemptions create different effects on heat produced in CHP plants and HO plants, and heat production from EBs and HPs. Future studies may look at the development of CHP in Nordic countries and propose other arrangements for tax rules that prevent these differences. A sensitivity analysis with different carbon and electricity prices could also be useful to conduct. The way the framework conditions are categorized may have an impact on the assessment. In reviewing the literature, no systematic categorization of framework conditions for the DH sector was identified, although Cagno et al. [115] categorize framework conditions for energy efficiency. Future analysis of the DH sector can be served by a defined structure for framework conditions. Countries planning to develop DH infrastructure can benefit from analysis of framework conditions and results, explaining what is cost-efficient and target-efficient [116].

\section{Conclusions}

This study gives a broad overview of Nordic $\mathrm{DH}$; the history of the development, the current position of Nordic DH and the framework conditions the $\mathrm{DH}$ sectors are facing. We have analysed the consequences of differences in framework conditions, and showed the impacts on differences in cost and income components in a model plant and a standard household. The Nordic DH sectors are characterized by a wide variety of fuels and technologies, and thus different regulations and different effects from framework conditions. 
This study shows that the model plant is profitable in operation in all the Nordic countries, but low $\mathrm{DH}$ prices and high investment costs may provide limited space for new investments. Investment subsidies have been important for the development of Nordic $\mathrm{DH}$, but the impact of such instruments is largest in the development phase or transition phases.

$\mathrm{DH}$ may have stronger competition from other heating options in Norway than in the other Nordic countries. That is especially the case when considering the relatively lower share of installed hydronic systems in Norwegian residential buildings. This seems to be among the main explanations for the relatively lower penetration of DH in Norway compared to Denmark, Finland and Sweden. Local commitment and $\mathrm{DH}$ as a political priority in an early development stage is another crucial factor for the development of Nordic DH.

Due to the well-established DH in Denmark, Finland and Sweden, and the characteristics of densification in Norway, consolidation rather than extensive new development is likely, and DH in Norway will develop but not catch up with the neighbouring countries. Future Nordic DH will be characterized by a high renewable share and will mainly be present in cities and towns. Future electricity prices and the energy policy, for instance the requirements for energy efficiency in buildings, define the future of Nordic $\mathrm{DH}$.

\section{Acknowledgments}

The authors would like to thank Thomas Aanensen and Ann Christin Bøeng (Statistics Norway), John Tang Jensen (The Danish District Heating Association), Maria Sidelnikova (The Norwegian Water Resources and Energy Directorate), Erik Thornström (The Swedish District Heating Association) and Taina Wilhelms (Finnish Energy) for sharing information and data. The study is funded by Energy Norway through the Flexelterm project (www.flexelterm.no), with co-funding from The Norwegian Research Council (under project no. 22620), for which we are grateful.

\section{Abbreviations}

The following abbreviations are used throughout this article.
A2A HP
Air-to-air heat pump
A2W HP
Air-to-water heat pump
CHP
Combined Heat and Power
$\mathrm{DH} \quad$ District heat/district heating
$\mathrm{EB} / \mathrm{EBs} \quad$ Electric boiler/electric boilers
$\mathrm{HO} \quad$ Heat-only (DH plants that only produces heat, not electricity)
HP/HP s Heat pump/heat pumps 
L2W HP Liquid-to-water heat pump

O\&M Operation and maintenance costs

$\mathrm{P} 2 \mathrm{H} \quad$ Power-to-heat technologies (electric boilers or heat pumps)

RES Renewable energy sources

\section{References}

[1] Directive 2010/31/EU of the European Parliament and of the Council of 19 May 2010 on the energy performance of buildings, URL http://eur-lex.europa.eu/legalcontent/en/TXT/?uri=CELEX: 32010L0031, online.

[2] Statistics Norway. District heating and cooling, URL https://www.ssb.no/energi-ogindustri/statistikker/fjernvarme/aar, online.

[3] L. D. Lucia, K. Ericsson, Low-carbon district heating in Sweden - Examining a successful energy transition, Energy Research \& Social Science 4 (2014) 10 - 20, ISSN 2214-6296, doi:〈bibinfo\{doi\}\{http://dx.doi.org/10.1016/j.erss.2014.08.005\},URL http://www.sciencedirect.com/science/article/pii/S2214629614000991.

[4] A. M. Hendricks, J. E. Wagner, T. A. Volk, D. H. Newman, Regional economic impacts of biomass district heating in rural New York, Biomass and Bioenergy 88 (2016) 1 - 9, ISSN 0961-9534, doi:\bibinfo\{doi\}\{http://dx.doi.org/10.1016/j.biombioe.2016.03.008\}, URL http://www. sciencedirect.com/science/article/pii/S0961953416300575.

[5] A. Colmenar-Santos, E. Rosales-Asensio, D. Borge-Diez, J.-J. Blanes-Peir'o, District heating and cogeneration in the EU-28: Current situation, potential and proposed energy strategy for its generalisation, Renewable and Sustainable Energy Reviews 62 (2016) 621 - 639, ISSN 1364-0321, doi:〈bibinfo\{doi\}\{http://dx.doi.org/10.1016/j.rser.2016.05.004\}, URL http://www.sciencedirect.com/science/article/pii/S1364032116301149.

[6] A. Lake, B. Rezaie, S. Beyerlein, Review of district heating and cooling systems for a sustainable future, Renewable and Sustainable Energy Reviews 67 (2017) 417 - 425, ISSN 1364-0321, doi:〈bibinfo\{doi\}\{http://dx.doi.org/10.1016/j.rser.2016.09.061\}, URL http://www.sciencedirect.com/science/article/pii/S1364032116305585.

[7] M. Wissner, Regulation of district-heating systems, Utilities Policy 31 (2014) 63 - 73, ISSN 0957-1787, doi:\bibinfo\{doi\}\{http://dx.doi.org/10.1016/j.jup.2014.09.001\}, URL http://www.sciencedirect.com/science/article/pii/S0957178714000629.

[8] S. Akhtari, T. Sowlati, K. Day, Economic feasibility of utilizing forest biomass in district energy systems - A review, Renewable and Sustainable Energy Reviews 33 (2014) 117 - 127, 
ISSN 1364-0321, doi:\bibinfo\{doi\}\{http://dx.doi.org/10.1016/j.rser.2014.01.058\}, URL http://www. sciencedirect.com/science/article/pii/S1364032114000690.

[9] R. Fazeli, B. Davidsdottir, J. H. Hallgrimsson, Residential energy demand for space heating in the Nordic countries: Accounting for interfuel substitution, Renewable and Sustainable Energy Reviews 57 (2016) 1210 - 1226, ISSN 1364-0321, doi:\bibinfo\{doi\}\{http://dx.doi.org/10.1016/j.rser.2015.12.184\}, URL http://www.sciencedirect.com/science/article/pii/S1364032115015671.

[10] A. Aslani, M. Naaranoja, K.-F. V. Wong, Strategic analysis of diffusion of renewable energy in the Nordic countries, Renewable and Sustainable Energy Reviews 22 (2013) 497 505, ISSN 1364-0321, doi:\bibinfo\{doi\}\{http://dx.doi.org/10.1016/j.rser.2013.01.060\}, URL http://www. sciencedirect.com/science/article/pii/S1364032113001081.

[11] A. Chittum, P. A. Østergaard, How Danish communal heat planning empowers municipalities and benefits individual consumers, Energy Policy 74 (2014) 465 - 474, ISSN 0301-4215, doi:\bibinfo\{doi\}\{http://dx.doi.org/10.1016/j.enpol.2014.08.001\}, URL http://www.sciencedirect.com/science/article/pii/S0301421514004546.

[12] T. Unger, E. O. Ahlgren, Impacts of a common green certificate market on electricity and CO2-emission markets in the Nordic countries, Energy Policy 33 (16) (2005) 2152 2163, ISSN 0301-4215, doi: \bibinfo\{doi\}\{http://dx.doi.org/10.1016/j.enpol.2004.04.013\}, URL http://www.sciencedirect.com/science/article/pii/S0301421504001223.

[13] H. K. Sjølie, E. Trømborg, B. Solberg, T. F. Bolkesjø, Effects and costs of policies to increase bioenergy use and reduce GHG emissions from heating in Norway, Forest Policy and Economics 12 (1)(2010) 57 - 66, ISSN 1389-9341, doi:\bibinfo\{doi\}\{http://dx.doi.org/10.1016/j.forpol.2009.08.011\}, URL http://www.sciencedirect.com/science/article/pii/S1389934109000975, forest sector models and their application.

[14] S. Werner, District heating and cooling in Sweden, Energy 126 (2017) 419-429, ISSN 0360-5442, doi: \bibinfo\{doi\}\{http://dx.doi.org/10.1016/j.energy.2017.03.052\}, URL http://www.sciencedirect.com/science/article/pii/S0360544217304140.

[15] P. Westin, F. Lagergren, Re-regulating district heating in Sweden, Energy Policy 30 (7) (2002) 583- 596, ISSN 0301-4215, doi:\bibinfo\{doi\}http://dx.doi.org/10.1016/S03014215(01)00126-4\}, URL http://www.sciencedirect.com/science/article/pii/S0301421501001264.

[16] K. Ericsson, S. Huttunen, L. J. Nilsson, P. Svenningsson, Bioenergy policy and market development in Finland and Sweden, Energy Policy 32 (15) (2004) 1707 - 1721, ISSN 03014215, doi: \bibinfo\{doi\}http://dx.doi.org/10.1016/S0301-4215(03)00161-7\}, URL http://www.sciencedirect. com/science/article/pii/S0301421503001617.

[17] B. K. Sovacool, Energy policymaking in Denmark: Implications for global energy security and sustainability, Energy Policy 61 (2013) 829 - 839, ISSN 0301-4215, 
doi:\bibinfo\{doi\}\{http: //dx.doi.org/10.1016/j.enpol.2013.06.106\}, URL

http://www.sciencedirect.com/science/article/pii/S0301421513006137.

[18] M. Forbord, J. Vik, B. G. Hillring, Development of local and regional forest based bioenergy in Norway - Supply networks, financial support and political commitment, Biomass and Bioenergy 47 (2012) 164 - 176, ISSN 0961-9534, doi:\bibinfo\{doi\}\{http://dx.doi.org/10.1016/j.biombioe.2012.09.045\}, URL http://www.sciencedirect.com/science/article/pii/S0961953412003856.

[19] E. Trømborg, M. Havskjold, O. Lislebø, P. K. Rørstad, Projecting demand and supply of forest biomass for heating in Norway, Energy Policy 39 (11) (2011) 7049 - 7058, ISSN 03014215, doi:\bibinfo\{doi\}http://dx.doi.org/10.1016/j.enpol.2011.08.009\}, URL http://www.sciencedirect.com/science/article/pii/S0301421511006069, Asian Energy Security.

[20] S. Helynen, Bioenergy policy in Finland, Energy for Sustainable Development 8 (1) (2004) 36 - 46, ISSN 0973-0826, doi:\bibinfo\{doi\}http://dx.doi.org/10.1016/S09730826(08)60389-0\}, URL http://www.sciencedirect.com/science/article/pii/S0973082608603890.

[21] A. Gebremedhin, Introducing District Heating in a Norwegian town - Potential for reduced Local and Global Emissions, Applied Energy 95 (2012) 300 - 304, ISSN 0306-2619, doi:\bibinfo\{doi\}\{http://dx.doi.org/10.1016/j.apenergy.2012.02.067\}, URL http://www.sciencedirect.com/science/article/pii/S0306261912001687.

[22] S. Paiho, F. Reda, Towards next generation district heating in Finland, Renewable and Sustainable Energy Reviews 65 (2016) 915 - 924, ISSN 1364-0321, doi:\bibinfo\{doi\}\{http://dx.doi.org/10.1016/j.rser.2016.07.049\}, URL http://www.sciencedirect.com/science/article/pii/S1364032116303768.

[23] P. A. Østergaard, A. N. Andersen, Booster heat pumps and central heat pumps in district heating, Applied Energy 184 (2016) 1374 - 1388, ISSN 0306-2619, doi:\bibinfo\{doi\}\{http://dx.doi.org/10.1016/j.apenergy.2016.02.144\}, URL http://www.sciencedirect.com/science/article/pii/S0306261916303105.

[24] Enova. The district heating program, URL https://www.enova.no/bedrift/energisystem/fjernvarme-og-fjernkjoling-/.

[25] The Danish District heating association. District heating price statistics, URL http://www. danskfjernvarme.dk/viden-om/statistik-subsection/varmeprisstatistik.

[26] Statistics Finland. Price of District Heating by Type of Consumer, URL http:// pxnet2.stat.fi/PXWeb/pxweb/en/StatFin/StatFin_ene_ehi/080_ehi_tau108_en.px/?rxid=4dd1684c-b437-4270-904b-a121fb827905.

[27] NVE 2015 report. Kostnader i energisektoren, URL publikasjoner.nve.no/rapport/2015/rapport201502a.pdf. 
[28] Swedish Energy Agency. Wood fuel and peat prices, URL http://www.energimyndigheten.se/globalassets/statistik/priser/sm1701 2.pdf.

[29] European Commission. Oil prices, URL http://ec.europa.eu/energy/en/dataanalysis/weekly-oil-bulletin.

[30] SKAT, the Danish Customs and Tax Administration, URL http://www.skat.dk/display.aspx?old=2060519\&vld=211712\&cnt=0.

[31] The Swedish Tax Agency. Tax rates, URL https://www.skatteverket.se/download/18. 361dc8c15312eff6fd37b84/1479991648676/2017+skattesatser+med+historik.xls.

[32] The Norwegian Tax Administration. Tax circulate on electricity, URL http://www.skatteetaten.no/globalassets/saravgifter/avgiftsrundskriv/2015-elektriskkraft.pdf.

[33] The Norwegian Tax Administration. Tax circulate on mineral products, URL http: //www.skatteetaten.no/no/Radgiver/Rettskilder/rundskriv-retningslinjer-og-andrerettskilder/avgiftsrundskriv/mineralske-produkter/.

[34] Act on excise duties on electricity and fuels, URL http://www.finlex.fi/sv/laki/ajantasa/1996/19961260.

[35] Eurostat. Labour costs, URL http://ec.europa.eu/eurostat/web/labour-market/labourcosts.

[36] Norges Bank. Exchange rates, URL http://www.norgesbank.no/Statistikk/Valutakurser/.

[37] Danmarks Nationalbank. Exchange rates, URL http://www.nationalbanken.dk/da/statistik/valutakurs/Sider/Default.aspx.

[38] The Riksbank. Exchange rates, URL http://www.riksbank.se/sv/Rantor-ochvalutakurser/Sok-rantor-och-valutakurser/.

[39] Mats Rosenberg 2010 Enova report. Kostnader for fjernvarmeutbygging, URL https://www.enova.no/download?objectPath=upload_images/45D005031D184BFFB2FC1F0 ECFAODCAE.pdf.

[40] Danish Energy Agency, Technology Data, Data catalogue for energy plants, URL https: //ens.dk/sites/ens.dk/files/Analyser/technology_data_catalogue_for_energy_plants__aug_2016._update_june_2017.pdf.

[41] M. H. Göran Koreneff, Antti Lehtilä, Nordic heating technology solution pathways, URL www.vtt.fi/inf/julkaisut/muut/2015/VTT-R-00587-15.pdf.

[42] J. Z. Thellufsen, Review of the Danish District Heating Sector: Technology for biomass in district heating (Internal document). 
[43] Danish Energy Agency. Technology Data, technology data for individual heating plants and energy transport, URL https://ens.dk/sites/ens.dk/files/Analyser/old technology data for individual heating plants and energy transport aug2016.pdf.

[44] I. Sarbu, C. Sebarchievici, General review of ground-source heat pump systems for heating and cooling of buildings, Energy and Buildings 70 (Supplement C) (2014) $441-454$, ISSN 0378-7788, doi:\bibinfo\{doi\}\{https://doi.org/10.1016/j.enbuild.2013.11.068\}, URL http://www.sciencedirect.com/science/article/pii/S0378778813007858.

[45] Bolius, URL https://www.bolius.dk/saa-meget-el-vand-og-varme-bruger-engennemsnitsfamilie-279/.

[46] A. Skov, J. Petersen, Dansk Fjernvarme, Odense Stadsarkiv, Dansk fjernvarme i 50 år: 1957-2007.

[47] D. Magnusson, Swedish district heating-A system in stagnation: Current and future trends in the district heating sector, Energy Policy 48 (2012) 449-459, ISSN 0301-4215, doi:|bibinfo\{doi\}\{http: //dx.doi.org/10.1016/j.enpol.2012.05.047\}, URL http://www.sciencedirect.com/science/article/pii/S0301421512004594, special Section: Frontiers of Sustainability.

[48] L. Koskelainen, R. Saarela, K. Sipilä, Kaukolämmön käsikirja (District heating manual), Energiate-ollisuus ry (Finnish Energy acc.), 566 s., URL www.energia.fi.

[49] E. Evensen, The Norwegian District Heating Association 20 year's anniversary edition.

[50] S. Jacobsson, The emergence and troubled growth of a 'biopower' innovation system in Sweden, Energy Policy 36 (4) (2008) 1491 - 1508, ISSN 0301-4215, doi:\bibinfo\{doi\}\{http://dx.doi.org/10.1016/j.enpol.2007.12.013\}, URL http://www.sciencedirect.com/science/article/pii/S0301421507005538.

[51] NVE licence data, URL https://www.nve.no/konsesjonssaker/.

[52] Eurostat table nrg 105a Supply, transformation and consumption of electricity annual data, URL http://ec.europa.eu/eurostat/data/database.

[53] Statistics Norway. Housing conditions. Survey on living conditions 2015, URL https://www.ssb.no/bygg-bolig-og-eiendom/statistikker/bo/hvert-3-aar/2015-11-25.

[54] NVE report. Kartlegging av oppvarmingsutstyr 2014, URL publikasjoner.nve.no/rapport/2014/rapport2014_85.pdf.

[55] Danish Energy Agency, URL https://ens.dk/sites/ens.dk/files/Statistik/elmaanedsstatistik_1709.xls.

[56] Statistics Denmark, URL http://www.statbank.dk/KN8Y.

[57] Euroheat. Country-by-country., URL http://www.euroheat.org/wpcontent/uploads/2016/03/2015-Country-by-country-Statistics-Overview.pdf. 
[58] Danish Energy Agency. Energy Statistics, URL

https://ens.dk/sites/ens.dk/files/Statistik/tabeller2015.xlsx.

[59] Swedish Energy Agency. Datafile "Energiläget i siffror", URL

http://www.energimyndigheten.se/globalassets/statistik/energilaget/energilaget-i-siffror2017.xlsx.

[60] Statistics Finland. Production of electricity and heat, URL http://www.stat.fi/til/salatuo/tau_en.html.

[61] Statistics Norway District heating and cooling, table 04730: Consumption of fuel used for gross production of district heating, by type of energy (GWh).

[62] D. M. Sneum, E. Sandberg, E. R. Soysal, K. Skytte, Framework conditions for flexibility in the district heating-electricity interface, URL

http://www.nordicenergy.org/publications/framework-conditions-for-flexibility-in-thedistrict-heating-electricity-interface/, Flex4RES 2016.

[63] EU directive on energy efficiency, URL http://data.europa.eu/eli/dir/2012/27/oj.

[64]The heat supply act, URL

https://www.retsinformation.dk/forms/R0710.aspx?id=165652.

[65] The District Heating Act, URL http://www.riksdagen.se/sv/dokument-

lagar/dokument/svensk-forfattningssamling/fjarrvarmelag-2008263 sfs-2008-263.

[66] The Energy Act, URL https://lovdata.no/lov/1990-06-29-50.

[67] P. E. Grohnheit, B. O. G. Mortensen, Competition in the market for space heating.

District heating as the infrastructure for competition among fuels and technologies, Energy Policy 31 (9) (2003) 817 - 826, ISSN 0301-4215, doi:\bibinfo\{doi\}\{http://dx.doi.org/10.1016/S0301-4215(02)00066-6\}, URL http://www.sciencedirect.com/science/article/pii/S0301421502000666.

[68] P. Söderholm, L. Wårell, Market opening and third party access in district heating networks, Energy Policy 39 (2) (2011) 742 - 752, ISSN 0301-4215, doi:\bibinfo\{doi\}\{http://dx.doi.org/10.1016/j. enpol.2010.10.048\}, URL http://www.sciencedirect.com/science/article/pii/S0301421510007998, special Section on Offshore wind power planning, economics and environment.

[69] P. Johansson, A. Nylander, F. Johnsson, Electricity dependency and CO2 emissions from heating in the Swedish building sector-Current trends in conflict with governmental policy?, Energy Policy 34 (17) (2006) 3049 - 3064, ISSN 0301-4215, doi:\bibinfo\{doi\}\{http://dx.doi.org/10.1016/j.enpol. 2005.05.012\}, URL http://www.sciencedirect.com/science/article/pii/S0301421505001515.

[70] The heat supply act $\S 11$, URL https://www.retsinformation.dk/forms/r0710.aspx?id=165652. 
[71] The heat supply act $\S 3$, URL

https://www.retsinformation.dk/forms/r0710.aspx?id=165652.

[72] The District Heating Act $\S 20$, URL

https://www.retsinformation.dk/forms/R0710.aspx?id=165652.

[73] The Energy Act § 5-5, URL https://lovdata.no/dokument/NL/lov/1990-06-29-

50/KAPITTEL 5\#5-2.

[74] The land use and building act §57a, URL

http://www.finlex.fi/sv/laki/ajantasa/1999/19990132.

[75] The energy act §5-3, URL https://lovdata.no/dokument/NL/lov/1990-06-29-50.

[76] The Energy Act §5-6, URL https://lovdata.no/dokument/NL/lov/1990-06-29-50.

[77] G. Heldesten, L. Tedebrand, L. W. Öhling, Swedish Energy Markets Inspectorate report 2013:4 "Reglerat tilträde till fjärrvärmenäten", Tech. Rep., Swedish Energy Markets Inspectorate, URL http://ei.se/Documents/Publikationer/rapporter och pm/Rapporter\\%202013/Ei R2013 04.pdf, 2013.

[78] World Bank. Indicators. Population density, URL

http://data.worldbank.org/indicator/EN.POP.DNST?view=chart.

[79] Eurostat. Distribution of population, URL

http://ec.europa.eu/eurostat/en/web/products-datasets/-/ILC_LVHO01.

[80] Enova, URL https://www.enova.no/privat/alle-energitiltak/varmepumper/.

[81] Enova, URL https://www.enova.no/privat/alle-energitiltak/biovarme/biokjel/.

[82] Enova, URL https://www.enova.no/privat/alle-energitiltak/varmepumper/vannbarenvarme-/.

[83] K. J. Haarberg, K. Elnan, A. H. Jan von Essen, T. Ekvall, J. Melbäck, Kostnader ved installasjon av vannbåren varme.", Tech. Rep., Enova/Prognosesenteret, URL https://www.enova.no/download?objectPath=upload_images/070C7178C728454C9F3ECED B070BF7CB.pdf, 2009.

[84] The Swedish Tax Agency. RME Installments, URL https://www.skatteverket.se/privat/fastigheterochbostad/rotochrutarbete/saharfungerarro tochrutavdraget.4.d5e04db14b6fef2c866097. html\#Rotochrutavdragetsstorlek.

[85] Regulation on excise duties § 3-12-5, URL https://lovdata.no/dokument/SF/forskrift/2001-12-11-1451/KAPITTEL 3-12\#3-12-1.

[86] Ellevio. Grid tariffs, URL https://www.ellevio.se/globalassets/uploads/dokument/nyaprislistor/avbr_alla_omr_160601_.pdf.

[87] Smedjebacken Energi \& Vatten AB, URL https://www.smedjebacken.se/seab/startsidaseab/toppmeny/elnat/elnatstariffer.106.37ae 3481363149b22b1064.html. 
[88] SKAT. The electric boiler scheme, URL http://www.skat.dk/skat.aspx?oid=1972881.

[89] S. Hellmer, Switching Costs, Switching Benefits and Lock-In Effects - The Reregulated Swedish Heat Market, Energy \& Environment 21 (6) (2010) 563-575, doi:\bibinfo\{doi\}\{10.1260/0958-305X.21.6.563\}, URL http://dx.doi.org/10.1260/0958305X.21.6.563.

[90] M. Albrecht, Enlightenment in Norway's Oil-Shadow? Governance Assemblages of a Wood-based District Heating Network in Norway's Inland Region, Journal of Environmental Policy \& Planning 17 (3) (2015) 381-401, doi: \bibinfo\{doi\}\{10.1080/1523908X.2014.964851\}, URL http://dx.doi.org/10. 1080/1523908X.2014.964851.

[91] E. Trømborg, T. F. Bolkesjø, B. Solberg, Impacts of policy means for increased use of forest-based bioenergy in Norway-A spatial partial equilibrium analysis, Energy Policy 35 (12) (2007) 5980 -5990, ISSN 0301-4215, doi:\bibinfo\{doi\}\{http://dx.doi.org/10.1016/j.enpol.2007.08.004\}, URL http: //www.sciencedirect.com/science/article/pii/S0301421507003540.

[92] R. E. Löfstedt, The use of biomass energy in a regional context: The case of Växjö Energi, Sweden, Biomass and Bioenergy 11 (1) (1996) 33 - 42, ISSN 0961-9534, doi:\bibinfo\{doi\}\{http://dx.doi.org/10.1016/0961-9534(96)00005-0\}, URL http://www.sciencedirect.com/science/article/pii/0961953496000050.

[93] J. Sjödin, D. Henning, Calculating the marginal costs of a district-heating utility, Applied Energy 78 (1) (2004) 1 - 18, ISSN 0306-2619, doi:\bibinfo\{doi\}\{http://dx.doi.org/10.1016/S0306-2619(03)00120-X\}, URL http://www.sciencedirect.com/science/article/pii/S030626190300120X.

[94] Danish District Heating Association District heating price statistics 2016, URL http://www.danskfjernvarme.dk/viden-om/statistiksubsection/varmeprisstatistik/fjernvarmeprisen-i-danmark-2016.

[95] S.-Y. Park, K.-S. Lee, S.-H. Yoo, Economies of scale in the Korean district heating system: A variable cost function approach, Energy Policy 88 (2016) 197 - 203, ISSN 0301-4215, doi: \bibinfo\{doi\}\{http://dx.doi.org/10.1016/j.enpol.2015.10.026\}, URL http://www.sciencedirect.com/science/article/pii/S0301421515301531.

[96] A. Kipping, E. Trømborg, Modeling hourly consumption of electricity and district heat in non-residential buildings, Energy 123 (Supplement C) (2017) 473 - 486, ISSN 0360-5442, doi:\bibinfo\{doi\}\{https://doi.org/10.1016/j.energy.2017.01.108\}, URL http://www.sciencedirect.com/science/article/pii/S0360544217301159.

[97] J. Patronen, E. Kaura, C. Torvestad, Nordic heating and cooling : Nordic approach to EU's Heating and Cooling Strategy.

[98] E. Bowitz, M. D. Trong, The social cost of district heating in a sparsely populated country, Energy Policy 29 (13) (2001) 1163 - 1173, ISSN 0301-4215, doi:〈bibinfo\{doi\}\{http://dx.doi.org/10.1016/S0301-4215(01)00039-8\}, URL http://www.sciencedirect.com/science/article/pii/S0301421501000398. 
[99] U. Persson, S. Werner, Heat distribution and the future competitiveness of district heating, Ap-plied Energy 88 (3) (2011) 568 - 576, ISSN 0306-2619, doi:\bibinfo\{doi\}\{http://dx.doi.org/10.1016/j.apenergy.2010.09.020\}, URL http://www.sciencedirect.com/science/article/pii/S0306261910003855.

[100] J. Unternährer, S. Moret, S. Joost, F. Maréchal, Spatial clustering for district heating integration in urban energy systems: Application to geothermal energy, Applied Energy 190 (2017) 749 - 763, ISSN 0306-2619, doi:\bibinfo\{doi\}\{http://dx.doi.org/10.1016/j.apenergy.2016.12.136\}, URL http://www.sciencedirect.com/science/article/pii/S0306261916319195.

[101] A. Karhunen, M. Laihanen, T. Ranta, Supply security for domestic fuels at Finnish combined heat and power plants, Biomass and Bioenergy 77 (2015) 45-52, ISSN 09619534, doi:\bibinfo\{doi\}\{http://dx.doi.org/10.1016/j.biombioe.2015.03.019\}, URL http://www.sciencedirect.com/science/article/pii/S0961953415001051.

[102] Nord Pool, URL https://www.nordpoolgroup.com/historical-market-data/.

[103] P. J. Agrell, P. Bogetoft, Economic and environmental efficiency of district heating plants, Energy Policy 33 (10) (2005) 1351 - 1362, ISSN 0301-4215, doi: \bibinfo\{doi\}\{http://dx.doi.org/10.1016/j.enpol.2003.12.011\}, URL http://www.sciencedirect.com/science/article/pii/S0301421503003793.

[104] A. Ambrose, W. Eadson, J. Pinder, The role of actor-networks in the early stage mobilisation of low carbon heat networks, Energy Policy 96 (2016) 144 - 152, ISSN 03014215, doi:\bibinfo\{doi\}\{http://dx.doi.org/10.1016/j.enpol.2016.05.042\}, URL http://www.sciencedirect.com/science/article/pii/S0301421516302725.

[105] D. Hawkey, J. Webb, District energy development in liberalised markets: situating UK heat network development in comparison with Dutch and Norwegian case studies, Technology Analysis \& Strategic Management 26 (10) (2014) 1228-1241, doi:\bibinfo\{doi\}\{10.1080/09537325.2014.971001\}, URL http:

//dx.doi.org/10.1080/09537325.2014.971001.

[106] K. McCormick, L. Neij, Experience of Policy Instruments for Energy Efficiency in Buildings in the Nordic Countries, Lund University, 2009.

[107] C. Reidhav, S. Werner, Profitability of sparse district heating, Applied Energy 85 (9) (2008)867-877, ISSN0306-2619, doi:\bibinfo\{doi\}\{http://dx.doi.org/10.1016/j.apenergy.2008.01.006\}, URL http://www.sciencedirect.com/science/article/pii/S0306261908000299.

[108] IEA Nordic Energy Technology Perspectives 2016, URL http://www.nordicenergy.org/project/nordic-energy-technology-perspectives/.

[109] M. Åberg, J. Widén, D. Henning, Sensitivity of district heating system operation to heat demand reductions and electricity price variations: A Swedish example, Energy 41 (1) (2012) 525 -540, ISSN 0360-5442, doi:|bibinfo\{doi\}\{http://dx.doi.org/10.1016/j.energy.2012.02.034\}, URL 
http://www.sciencedirect.com/science/article/pii/S0360544212001296, 23rd International Conference on Efficiency, Cost, Optimization, Simulation and Environmental Impact of Energy Systems, ECOS 2010.

[110] M. Salomón, T. Savola, A. Martin, C.-J. Fogelholm, T. Fransson, Small-scale biomass CHP plants in Sweden and Finland, Renewable and Sustainable Energy Reviews 15 (9) (2011) 4451 - 4465, ISSN 1364-0321, doi:\bibinfo\{doi\}\{http://dx.doi.org/10.1016/j.rser.2011.07.106\}, URL http://www. sciencedirect.com/science/article/pii/S1364032111003510.

[111] J. Kalina, Complex thermal energy conversion systems for efficient use of locally available biomass, Energy 110 (2016) 105 - 115, ISSN 0360-5442, doi:\bibinfo\{doi\}\{http://dx.doi.org/10.1016/j.energy. 2016.02.164\}, URL http://www.sciencedirect.com/science/article/pii/S0360544216302262, special issue on Smart Energy Systems and 4th Generation District Heating.

[112] I. Keppo, T. Savola, Economic appraisal of small biofuel fired CHP plants, Energy Conversion and Management 48 (4) (2007) 1212 - 1221, ISSN 0196-8904, doi:〈bibinfo\{doi\}\{http: //dx.doi.org/10.1016/j.enconman.2006.10.010\}, URL http://www.sciencedirect.com/science/article/pii/S0196890406003232.

[113] A. Gebremedhin, J. D. O. Granheim, Is there a space for additional renewable energy in the Norwegian power system? Potential for reduced global emission?, Renewable and Sustainable Energy Reviews 16 (3) (2012) 1611 - 1615, ISSN 1364-0321, doi:\bibinfo\{doi\}\{http://dx.doi.org/10.1016/j.rser.2011.11.032\}, URL http://www.sciencedirect.com/science/article/pii/S1364032111005788.

[114] R. S. Kempegowda, Øyvind Skreiberg, K.-Q. Tran, Techno-economic Evaluations of Various Biomass CHP Technologies and Policy Measures Under Norwegian Conditions, Energy Procedia 20 (2012) 1 - 10, ISSN 1876-6102, doi:〈bibinfo\{doi\}\{http://dx.doi.org/10.1016/j.egypro.2012.03.002\}, URL http: //www.sciencedirect.com/science/article/pii/S1876610212007321, technoport 2012 Sharing Possibilities and 2nd Renewable Energy Research Conference (RERC2012).

[115] E. Cagno, E. Worrell, A. Trianni, G. Pugliese, A novel approach for barriers to industrial energy efficiency, Renewable and Sustainable Energy Reviews 19 (Supplement C) (2013) 290 - 308, ISSN 1364- 0321, doi:\bibinfo\{doi\}\{https://doi.org/10.1016/j.rser.2012.11.007\}, URL http://www.sciencedirect. com/science/article/pii/S1364032112006181.

[116] Euroheat News, URL https://www.euroheat.org/news/district-heating-hot-topicdublin/, online.[117] Danish District Heating Association District heating price statistics 2015, URL http://www.danskfjernvarme.dk/viden-om/statistiksubsection/varmeprisstatistik/fjernvarmeprisen-i-danmark-2015.

[118] Statistics Finland Energy statistics Price of district heat, URL http://pxnet2.stat.fi/PXWeb/pxweb/en/StatFin/StatFin_ene_ehi/080_ehi_tau_108_en.px/? rxid=2fb7cf43-6d91-447d-b95b-861a24eb9274. 
[119] Statistics Norway District heating and district cooling 2016, URL

https://www.ssb.no/en/energi-og-industri/statistikker/fjernvarme, table: 04729: Technical and economic main figures.

[120] European Commission, URL https://ec.europa.eu/energy/en/data-analysis/weekly-oilbulletin.

[121] The Danish Customs and Tax Administration, URL

http://skat.dk/skat.aspx?olD=1921342\&chk=214580.

[122] Finlex, URL http://www.finlex.fi/sv/laki/ajantasa/1996/19961260.

[123] The Norwegian Tax Administration, URL

http://www.skatteetaten.no/no/Radgiver/Rettskilder/rundskriv-retningslinjer-og-andrerettskilder/avgiftsrundskriv/mineralske-produkter/.

[124] The Swedish Tax Agency, URL

https://www4.skatteverket.se/rattsligvagledning/edition/2015.16/323440.html.

[125] Index Mundi, URL http://www.indexmundi.com/commodities/?commodity=naturalgas\&months $=60 \&$ currency $=$ eur. $60 \&$ currency $=e u r$.

[126] Gaspint Nordic, URL http://www.gaspointnordic.com/market-data.

[127] Statistics Finland, wood chips, URL

http://pxnet2.stat.fi/PXWeb/pxweb/en/StatFin/StatFin_ene_ehi/020_ehi_tau_102_en.px/? rxid=fdd584d0-fdfb-4fb0-b925-9f2d87fc857f.

[128] Statistics Finland, wood pellets, URL http://www.stat.fi/til/thi/2016/01/thi_2016_01_2016-02-24_tau_025_en.html.

[129] Swedish Energy Agency, URL

http://www.energimyndigheten.se/globalassets/statistik/priser/tidserier_tradbransle_och_ torvpriser_master_webben-ver01.xls.

[130] Eurostat: Electricity prices for household consumers, URL

http://ec.europa.eu/eurostat/statistics-

explained/index.php/Electricity_price_statistics\#Further_Eurostat_information.

[131] Bolius fuel prices, URL https://www.bolius.dk/pristest-her-er-de-billigstebraendepriser-i-2016-29632/.

[132] Pilkenetti Oy. Pellet prices, URL http://pilkenetti.valmiskauppa.fi/kpl60lpakattunahuomtoimitus-sishintaan-p-774.html.

[133] Statistics Norway. Commercial Roundwood removals, URL https://www.ssb.no/statistikkbanken/SelectVarVal/Define.asp?MainTable=AvvirkSalg14\&Ko rtNavnWeb=skogav\&PLanguage $=0$ \&checked $=$ true.

[134] Vedservice. Firewood prices, URL: http://vedservice.se/prislista-2016.html. 
[135] Storsmeden Ved. Firewood prices, URL

http://www.storsvedenved.se/priser_och_bestallning.php.

[136] Danish Energy Regulatory Authority. Natural gas price statistics, URL

http://energitilsynet.dk/fileadmin/Filer/0_-

_Nyt_site/GAS/Prisstatistik/2016/Naturgasstatistik_3._kvt._2016.pdf.

[137] The Danish Ministry of Taxation, URL http://www.skm.dk/skattetal/satser/satser-ogbeloebsgraenser.

[138] Energy and oil forum. Fuel oil prices, URL http://www.eof.dk/Priser-ogForbrug/Fyringsolie-udvikling.

[139] Statistics Finland, URL http://www.stat.fi/til/ehi/2016/03/ehi 201603 2016-12-08 tau 003 en.html.

[140] Norwegian Petroleum Institute. Prices, URL http://www.np.no/priser/.

[141] Danish Energy Agency. Social economic analysis, URL

https://ens.dk/service/fremskrivninger-analyser-modeller/samfundsoekonomiske-

analysemetoder.

[142] Byggmax. Pellets and firewood prices, URL

https://www.byggmax.no/oppvarming/pellets-och-ved.

[143] Derome pellets. Pellet prices, URL http://www.deromepellets.se/

[144] HGL bränsle. Pellet price, URL

http://www.hglbransle.se/HGLBr\\%C3\\%A4nsle/Pellets.aspx.

[145] Statistics Norway. District heating and district cooling, table: 04727: Balance of district heating (GWh).

[146] Statistics Finland. Production and consumption of district heat, URL http:// pxnet2.stat.fi/PXWeb/pxweb/en/StatFin/StatFin_ene_ehk/090_ehk_tau_109_en.px/?rxid=2 8636a5b-5284-4678-bfc1-760863b9e667.

[147] The Swedish association of energy companies. District heating statistics, URL https://www.energiforetagen.se/link/b7fd9cfdef5c4527a7742347adc3add3.aspx?v=nonce4806b8a4-04c7-4b42-ac6e-c06728f60666, delivered district heat.

[148] District Energy in Denmark, URL https://www.euroheat.org/knowledgecentre/district-energy-denmark/.

[149] District Energy in Finland, URL https://www.euroheat.org/knowledge-centre/districtenergy-finland/.

[150] District Energy in Norway, URL https://www.euroheat.org/knowledge-centre/districtenergy-norway/.

[151] District Energy in Sweden, URL https://www.euroheat.org/knowledge-centre/districtenergy-sweden/. 
[152] Statistics Sweden, URL

http://www.statistikdatabasen.scb.se/pxweb/sv/ssd/START_EN_EN0105/BrforangaAR/?rxid =020467db-9ee9-40fc-bd1d-daa8d6d347ea.

[153] Danish District Heating Association. Statistics, URL http://www.danskfjernvarme.dk/viden-om/aarsstatistik.

[154] Finnish Energy. District heating statistics, URL http://energia.fi/en/statistics-andpublications/district-heating-statistics/district-heating.

[155] Statistics Norway. District heating and district cooling, URL https://www.ssb.no/energi-og-industri/statistikker/fjernvarme/aar/2016-0513?fane=tabell\&sort=nummer\&tabell=265891, table 09469: Net production of district heating, by type of heat central.

[156] The Swedish association of energy companies. District heating statistics. Consumer distribution, URL https://www.energiforetagen.se/statistik/fjarrvarmestatistik/kundtyper/.

[157] Statistics Norway, extracted data by Thomas Aanesen.

[158] Swedish Energy Market Inspectorate. Datafile "Fjärrvärmekollen", URL http://ei.se/start-fjarrvarmekollen/foretag/. 
Table 1: Framework conditions for Nordic district heating, categorized and explained

\begin{tabular}{|c|c|c|c|c|c|}
\hline Frameworl & condition & Explanation & $\begin{array}{l}\text { Driver/barrier } \\
\text { for }\end{array}$ & $\begin{array}{l}\text { Driver/barrier } \\
\text { for operation }\end{array}$ & Sources \\
\hline & Tax reduction & $\begin{array}{l}\text { Tax benefits for } \\
\text { certain target } \\
\text { groups }\end{array}$ & $\begin{array}{l}\text { Reduces } \\
\text { production } \\
\text { costs }\end{array}$ & $\begin{array}{l}\text { Reduces fuel } \\
\text { costs }\end{array}$ & $\begin{array}{l}\text { Tax } \\
\text { authorities }\end{array}$ \\
\hline & Flexible grid tariffs & $\begin{array}{l}\text { A reduced grid } \\
\text { tariff for } \\
\text { electricity use }\end{array}$ & $\begin{array}{l}\text { Reduces costs } \\
\text { of } \mathrm{P} 2 \mathrm{H}\end{array}$ & $\begin{array}{l}\text { Reduces } \\
\text { electricity } \\
\text { costs }\end{array}$ & $\begin{array}{l}\text { Distribution } \\
\text { system } \\
\text { operators } \\
\text { (DSOs) }\end{array}$ \\
\hline Economic & $\begin{array}{l}\text { Feed-in } \\
\text { tariffs/Feed-in } \\
\text { premiums/Green } \\
\text { certificates }\end{array}$ & $\begin{array}{l}\text { Production based } \\
\text { support schemes }\end{array}$ & $\begin{array}{l}\text { Increases } \\
\text { profitability }\end{array}$ & $\begin{array}{l}\text { Increases } \\
\text { profit }\end{array}$ & $\begin{array}{l}\text { Law on the } \\
\text { Promotion of } \\
\text { Renewabable } \\
\text { energy } \\
\text { (Denmark), } \\
\text { Act on the } \\
\text { Production } \\
\text { Subsidy for } \\
\text { Electricity } \\
\text { Produced } \\
\text { from } \\
\text { Renewable } \\
\text { Energy } \\
\text { Sources } \\
\text { (Finland), The } \\
\text { Electricity } \\
\text { Certificate Act } \\
\text { (Norway and } \\
\text { Sweden) }\end{array}$ \\
\hline & $\begin{array}{l}\text { Investment } \\
\text { subsidy }\end{array}$ & $\begin{array}{l}\text { The State covers a } \\
\text { certain part of the } \\
\text { investment costs }\end{array}$ & $\begin{array}{l}\text { Reduces } \\
\text { investment } \\
\text { costs }\end{array}$ & $\begin{array}{l}\text { Increases } \\
\text { profit }\end{array}$ & $\begin{array}{l}\text { Enova, the } \\
\text { Norwegian } \\
\text { organisation } \\
\text { for faciliating } \\
\text { renewable }\end{array}$ \\
\hline
\end{tabular}


energy

projects

\begin{tabular}{|c|c|c|c|c|c|}
\hline & Price/profit cap & $\begin{array}{l}\text { A maximum } \mathrm{DH} \\
\text { price/requirement } \\
\text { to break even }\end{array}$ & $\begin{array}{l}\text { Limits the DH } \\
\text { producer's } \\
\text { profit, but } \\
\text { protects the } \\
\text { consumers }\end{array}$ & Reduces profit & $\begin{array}{l}\text { The Energy } \\
\text { Act } \\
\text { (Norway)/The } \\
\text { Heat Supply } \\
\text { Act } \\
\text { (Denmark) }\end{array}$ \\
\hline Other & Heat plan & $\begin{array}{l}\text { The municipalities } \\
\text { are required to } \\
\text { formulate a heat } \\
\text { plan for the local } \\
\text { heat supply }\end{array}$ & $\begin{array}{l}\text { Contributes to } \\
\text { predictability }\end{array}$ & $\begin{array}{l}\text { Ensures base } \\
\text { for operation }\end{array}$ & $\begin{array}{l}\text { The Heat } \\
\text { Supply Act } \\
\text { (Denmark) }\end{array}$ \\
\hline
\end{tabular}

Table 2: Technical specifications of the model plant

\begin{tabular}{lr} 
Model plant & \\
\hline Interest rate & $4 \%$ \\
Longevity heating central and network & 20 years \\
Installed capacity wood chip boiler & $10 \mathrm{MW}$ \\
Installed capacity oil boiler & $10 \mathrm{MW}$ \\
Efficiency wood chip boiler & $91 \%$ \\
Efficiency oil boiler & $92 \%$ \\
& 36400 \\
District heat production wood chip boiler & $\mathrm{MWh}$ \\
& 4600 \\
District heat production oil boiler & $\mathrm{MWh}$ \\
Heat loss & $10 \%$ \\
Number of employees & 2 \\
Length of network & $15 \mathrm{~km}$ \\
Pipe dimension & DN200 \\
Number of consumer centrals & 10 \\
Ground & Asphalt \\
Location & City
\end{tabular}


Table 3: Assumption for options for space and tap water heating

\section{Example building}

Heat demand

Average outdoor temperature

\section{8}

MWh/year

$8{ }^{\circ} \mathrm{C}$

\begin{tabular}{|c|c|c|c|c|c|}
\hline Technology & $\begin{array}{l}\text { Efficiency } \\
(\%)^{*}\end{array}$ & $\begin{array}{l}\text { Auxilliary } \\
\text { electricity } \\
\text { consumption } \\
\text { MWh/year }\end{array}$ & $\begin{array}{l}\text { Technical } \\
\text { lifetime }\end{array}$ & $\begin{array}{l}\text { Share of } \\
\text { space } \\
\text { heating } \\
\text { demand } \\
\text { covered by } \\
\text { unit (\%) }\end{array}$ & $\begin{array}{l}\text { Share of } \\
\text { hot tap } \\
\text { water } \\
\text { demand } \\
\text { covered by } \\
\text { unit (\%) }\end{array}$ \\
\hline $\begin{array}{l}\text { Air-to-air heat pump (A2A HP) and } \\
\text { direct electric heating }\end{array}$ & 250 & 10.3 & 10 & 60 & 0 \\
\hline Air-to-water heat pump (A2W HP) & 250 & 0.1 & 15 & 100 & 100 \\
\hline Liquid-to-water heat pump (L2W & & & & & \\
\hline HP) & 320 & 0.1 & 20 & 100 & 100 \\
\hline Direct electric space and water & & & & & \\
\hline heating & 100 & - & 30 & 100 & 100 \\
\hline Natural gas boiler & 92 & 0.2 & 22 & 100 & 100 \\
\hline Oil boiler & 80 & 0.4 & 20 & 90 & 80 \\
\hline Wood pellets boiler & 90 & 2.8 & 20 & 90 & 80 \\
\hline $\begin{array}{l}\text { Firewood stove and direct electric } \\
\text { heating }\end{array}$ & 65 & 10.3 & 24 & 60 & 0 \\
\hline District heating & 98 & & 20 & 100 & 100 \\
\hline
\end{tabular}


* For heat pumps, a fuel efficiency of e.g. $300 \%$ represents a coefficient of performance (COP) of 3. The COP is the ratio of delivered heat to the electricity input. An interest rate of $4 \%$ is used in the calculations of capital costs.

Table 4: Current framework conditions for district heating in the Nordic countries

\begin{tabular}{|c|c|c|c|c|c|c|}
\hline & \multicolumn{2}{|c|}{ Framework conditions for district heating } & $\begin{array}{l}\text { Denmar } \\
\mathbf{k}\end{array}$ & $\begin{array}{l}\text { Finlan } \\
\text { d }\end{array}$ & $\begin{array}{l}\text { Norwa } \\
\text { y }\end{array}$ & $\begin{array}{l}\text { Swede } \\
\mathrm{n}\end{array}$ \\
\hline \multirow{10}{*}{ Drivers } & \multirow{8}{*}{$\begin{array}{c}\text { Economi } \\
\mathrm{c}\end{array}$} & Tax exemption for renewable fuels & $V$ & V & $V$ & $V$ \\
\hline & & $\begin{array}{l}\text { Investment subsidy for renewable } \\
\text { based district heating }\end{array}$ & $x$ & $x$ & $\boldsymbol{V}$ & $x$ \\
\hline & & $\begin{array}{l}\text { Reduced energy tax on fuels for } \\
\text { district heat production }\end{array}$ & $\nu$ & $x$ & $x$ & $\nu$ \\
\hline & & $\begin{array}{l}\text { Reduced } \mathrm{CO}_{2} \text { tax on fuels for district } \\
\text { heat production }\end{array}$ & $V$ & $V$ & $V$ & $V$ \\
\hline & & $\begin{array}{l}\text { Reduced electricity tax for district heat } \\
\text { production }\end{array}$ & $V$ & $V$ & $V$ & $x$ \\
\hline & & Flexible grid tariffs & $x$ & $x$ & $V$ & $V$ \\
\hline & & $\begin{array}{l}\text { Feed-in tariffs/green certificates for } \\
\text { electricity from cogeneration }\end{array}$ & $V$ & $\boldsymbol{V}$ & $\boldsymbol{V}$ & $V$ \\
\hline & & $\begin{array}{l}\text { Power capacity payments for } \\
\text { cogeneration plants }\end{array}$ & $V$ & $x$ & $x$ & $x$ \\
\hline & \multirow{2}{*}{ Other } & Heat plan & V & $x$ & $x$ & $x$ \\
\hline & & Mandatory connection & V & V & V & $x$ \\
\hline \multirow{3}{*}{$\begin{array}{c}\text { Barrier } \\
\mathrm{s}\end{array}$} & & Price cap on district heat & $x$ & $x$ & V & $x$ \\
\hline & $c$ & $\begin{array}{l}\text { Profit cap for commercially owned } \\
\text { district heat generators }\end{array}$ & V & $x$ & $x$ & $x$ \\
\hline & Other & Third party access & $V$ & $V$ & $x$ & $x$ \\
\hline
\end{tabular}

Yes $-V$ No $-\boldsymbol{X}$ 
Table 5: Average district heating prices

$\begin{array}{llll}\text { Average district heating } & 2016 & 2015 & \text { Source } \\ \text { price }(€ / M W h, \text { excl. VAT) } & & & \end{array}$

Denmark 75

72 Danish District Heating

Association [117][94]

Finland

59

59

Statistics Finland [118]

Norway

72

64

Statistics Norway [119]

Sweden

80

60

Swedish Energy

Agency [28] 
Table 6: Fuel prices for district heat producers $€ / M W h$

\begin{tabular}{|c|c|c|c|c|c|c|}
\hline $\begin{array}{l}\text { Fuel } \\
\text { costs } \\
2015\end{array}$ & Country & $\begin{array}{l}\text { Fuel } \\
\text { price }\end{array}$ & $\begin{array}{c}\text { Energy } \\
\text { tax }\end{array}$ & $\begin{array}{c}\mathrm{CO} 2 \\
\operatorname{tax}\end{array}$ & Sum & Source \\
\hline \multirow[t]{4}{*}{ Fuel oil } & Denmark & 27.4 & 22.0 & 5.3 & 55.6 & $\begin{array}{lll}\text { European } & \text { Commission [120], The } \\
\text { Danish Customs and Tax } \\
\text { Administration [121] }\end{array}$ \\
\hline & Finland & 27.6 & 8.5 & 10.4 & 46.5 & $\begin{array}{lll}\text { European } & \text { Commission } \\
\text { Finlex [122] }\end{array}$ \\
\hline & Norway & 27.6 & 15.7 & 8.9 & 52.2 & $\begin{array}{l}\text { European Commission [120], The } \\
\text { Norwegian Tax Administration } \\
\text { [123] }\end{array}$ \\
\hline & Sweden & 27.6 & 17.3 & 30.4 & 75.3 & $\begin{array}{l}\text { European Commission [120], The } \\
\text { Swedish Tax Agency [124] }\end{array}$ \\
\hline \multirow[t]{4}{*}{$\begin{array}{l}\text { Natural } \\
\text { gas }\end{array}$} & Denmark & 22.4 & - & 5.1 & 27.5 & $\begin{array}{l}\text { Index Mundi [125], The Danish } \\
\text { Customs and Tax Administration } \\
\text { [121] }\end{array}$ \\
\hline & Finland & 22.4 & 6.7 & 8.7 & 37.8 & Index Mundi [125], Finlex [122] \\
\hline & Norway & 22.4 & - & 1.0 & 23.4 & $\begin{array}{l}\text { Index Mundi [125], The Norwegian } \\
\text { Tax Administration [123] }\end{array}$ \\
\hline & Sweden & 22.4 & 9.1 & 18.1 & 49.7 & $\begin{array}{l}\text { Index Mundi [125], The Swedish } \\
\text { Tax Agency [124] }\end{array}$ \\
\hline \multirow[t]{2}{*}{ LPG } & Denmark & 92.9 & 34.0 & 5.3 & 133.2 & $\begin{array}{l}\text { Gaspoint Nordic [126], The Danish } \\
\text { Customs and Tax Administration } \\
\text { [121] }\end{array}$ \\
\hline & Finland & 92.9 & 13.2 & 25.0 & 131.1 & Gaspoint Nordic [126], Finlex [122] \\
\hline
\end{tabular}




\begin{tabular}{|c|c|c|c|c|c|c|}
\hline & Norway & 92.9 & - & - & 92.9 & $\begin{array}{l}\text { Gaspoint } \\
\text { Norwegian } \\
\text { [123] }\end{array}$ \\
\hline & Sweden & 92.9 & 10.2 & 16.8 & 119.9 & $\begin{array}{l}\text { Gaspoint Nordic [126], } \\
\text { Swedish Tax Agency [124] }\end{array}$ \\
\hline \multirow{4}{*}{$\begin{array}{l}\text { Wood } \\
\text { chips }\end{array}$} & Denmark & 17.4 & - & - & 17.4 & The Danish District Heating \\
\hline & Finland & 14.8 & - & - & 14.8 & $\begin{array}{l}\text { Association [121] } \\
\text { Statistics Finland [127][128] }\end{array}$ \\
\hline & Norway & 13.2 & - & - & 13.2 & $\begin{array}{l}\text { The Norwegian Water Resources } \\
\text { and Energy Directorate [27] }\end{array}$ \\
\hline & Sweden & 13.8 & - & - & 13.8 & The Swedish Energy Agency [129] \\
\hline \multirow{4}{*}{$\begin{array}{l}\text { Wood } \\
\text { pellets }\end{array}$} & Denmark & 36.5 & - & - & 36.5 & $\begin{array}{l}\text { The Danish District Heating } \\
\text { Association [121] }\end{array}$ \\
\hline & Finland & 44.6 & - & - & 44.6 & Statistics Finland [127][128] \\
\hline & Norway & 38.5 & - & - & 38.5 & $\begin{array}{l}\text { The Norwegian Water Resources } \\
\text { and Energy Directorate [27] }\end{array}$ \\
\hline & Sweden & 30.6 & - & - & 30.6 & The Swedish Energy Agency [129] \\
\hline
\end{tabular}

Table 7: Fuel costs for households $2016 € / \mathrm{MWh}$

\begin{tabular}{|c|c|c|c|c|c|c|c|}
\hline $\begin{array}{l}\text { Fuel } \\
\text { costs } \\
2016\end{array}$ & Country & $\begin{array}{l}\text { Fuel } \\
\text { price }\end{array}$ & $\begin{array}{l}\text { Grid } \\
\text { tariffs }\end{array}$ & $\begin{array}{l}\text { Energy } \\
\text { tax }\end{array}$ & $\begin{array}{l}\mathrm{CO} 2 \\
\operatorname{tax}\end{array}$ & Sum & Source \\
\hline \multirow{4}{*}{ Electricity } & Denmark & 37 & 46 & 138 & - & 221 & Eurostat [130] \\
\hline & Finland & 41 & 28 & 44 & - & 113 & Eurostat [130] \\
\hline & Norway & 37 & 29 & 38 & - & 104 & Eurostat [130] \\
\hline & Sweden & 42 & 41 & 57 & - & 14 & Eurostat [130] \\
\hline \multirow{4}{*}{ Firewood } & Denmark & 73 & - & - & - & 73 & Bolius [131] \\
\hline & Finland & 47 & - & - & - & 47 & Pilkenetti Oy [132] \\
\hline & Norway & 50 & - & - & - & 50 & Statistics Norway [133] \\
\hline & Sweden & 29 & - & - & - & 29 & $\begin{array}{l}\text { Vedservice } \\
\text { Storsveden ved [135], }\end{array}$ \\
\hline $\begin{array}{l}\text { Natural } \\
\text { gas }\end{array}$ & Denmark & 20 & 13 & 27 & 5 & 65 & $\begin{array}{l}\text { Danish Energy Regulatory } \\
\text { Authority [136], The Danish } \\
\text { Ministry of Taxation [137] }\end{array}$ \\
\hline \multirow{4}{*}{ Oil } & Denmark & 63 & - & 27 & 6 & 96 & $\begin{array}{l}\text { Energy and oil forum [138], } \\
\text { The Danish Ministry of } \\
\text { Taxation [137] }\end{array}$ \\
\hline & Finland & 42 & - & 7 & 7 & 56 & $\begin{array}{l}\text { Statistics Finland [139], } \\
\text { European Commission [29] }\end{array}$ \\
\hline & Norway & 48 & - & 17 & 13 & 78 & $\begin{array}{ll}\text { Norwegian } & \text { Petroleum } \\
\text { Institute [140] } & \\
\end{array}$ \\
\hline & Sweden & 39 & - & 9 & 34 & 82 & $\begin{array}{l}\text { European Commission [29], } \\
\text { The Swedish Tax Agency }\end{array}$ \\
\hline
\end{tabular}




\begin{tabular}{llllllll}
\hline & & & & & & & {$[124]$} \\
\hline \multirow{4}{*}{$\begin{array}{l}\text { Wood } \\
\text { pellets }\end{array}$} & Denmark & 50 & - & - & - & 50 & $\begin{array}{l}\text { Danish Energy Agency } \\
{[141]}\end{array}$ \\
\cline { 2 - 8 } & Finland & 46 & - & - & - & 46 & Statistics Finland [139] \\
\cline { 2 - 8 } & Norway & 53 & - & - & - & 53 & Byggmax [142] \\
\cline { 2 - 8 } & Sweden & 75 & - & - & - & 75 & $\begin{array}{l}\text { Derome pellets [143], HGL } \\
\text { bränsle [144] }\end{array}$ \\
\hline
\end{tabular}

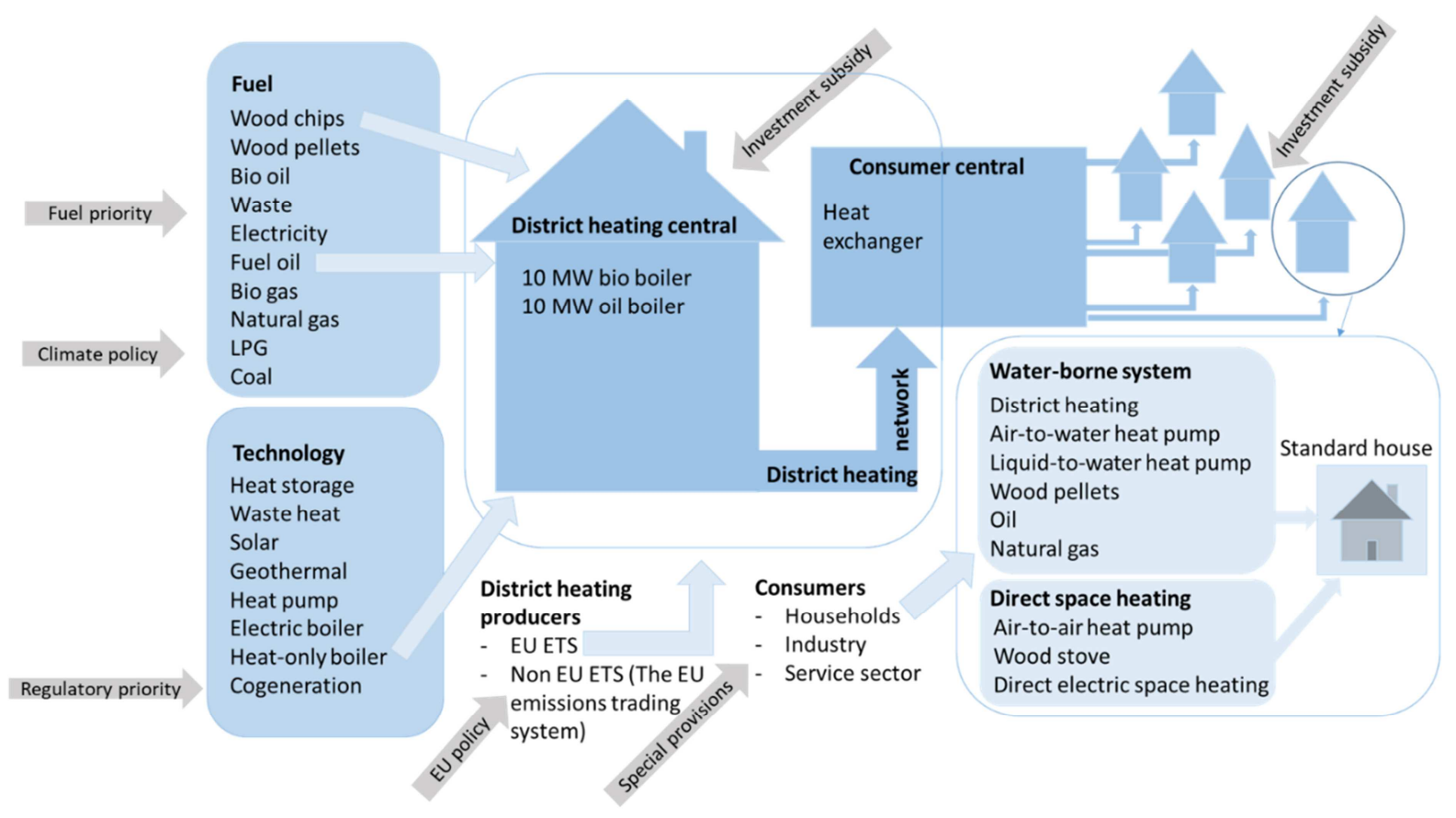

Figure 1: A district heating system, framework conditions and the delineation of this study 
70

60

50

40

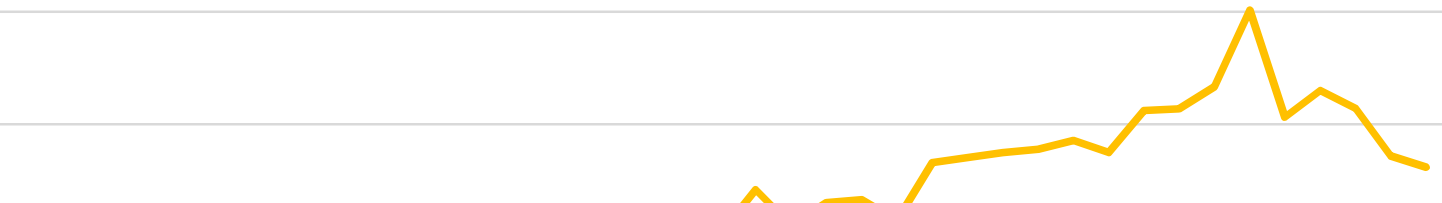

30

20

10

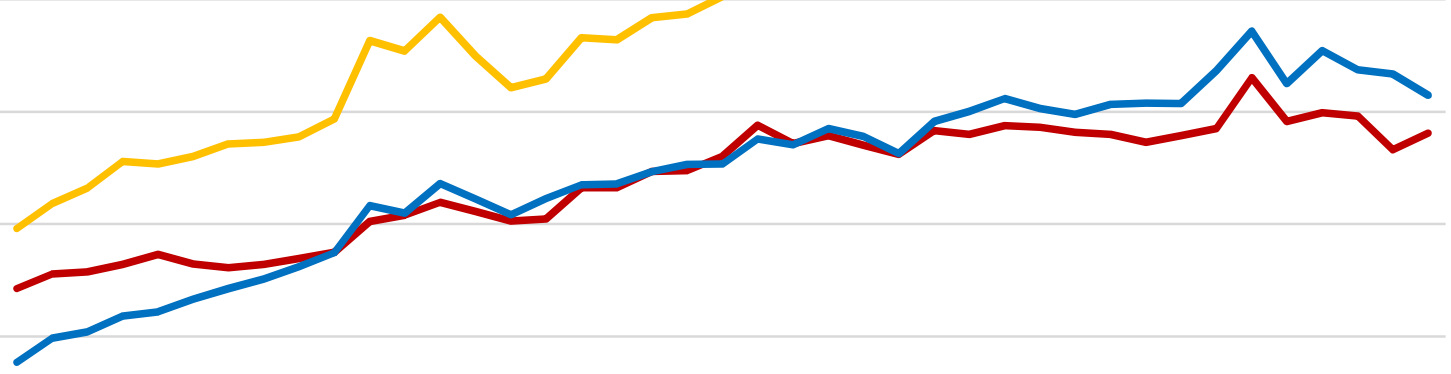

0 197519771979198119831985198719891991199319951997199920012003200520072009201120132015 Denmark Finland Norway Sweden

Figure 2: Delivered district heat 1975-2015 Sources: [145][58][146][147] 


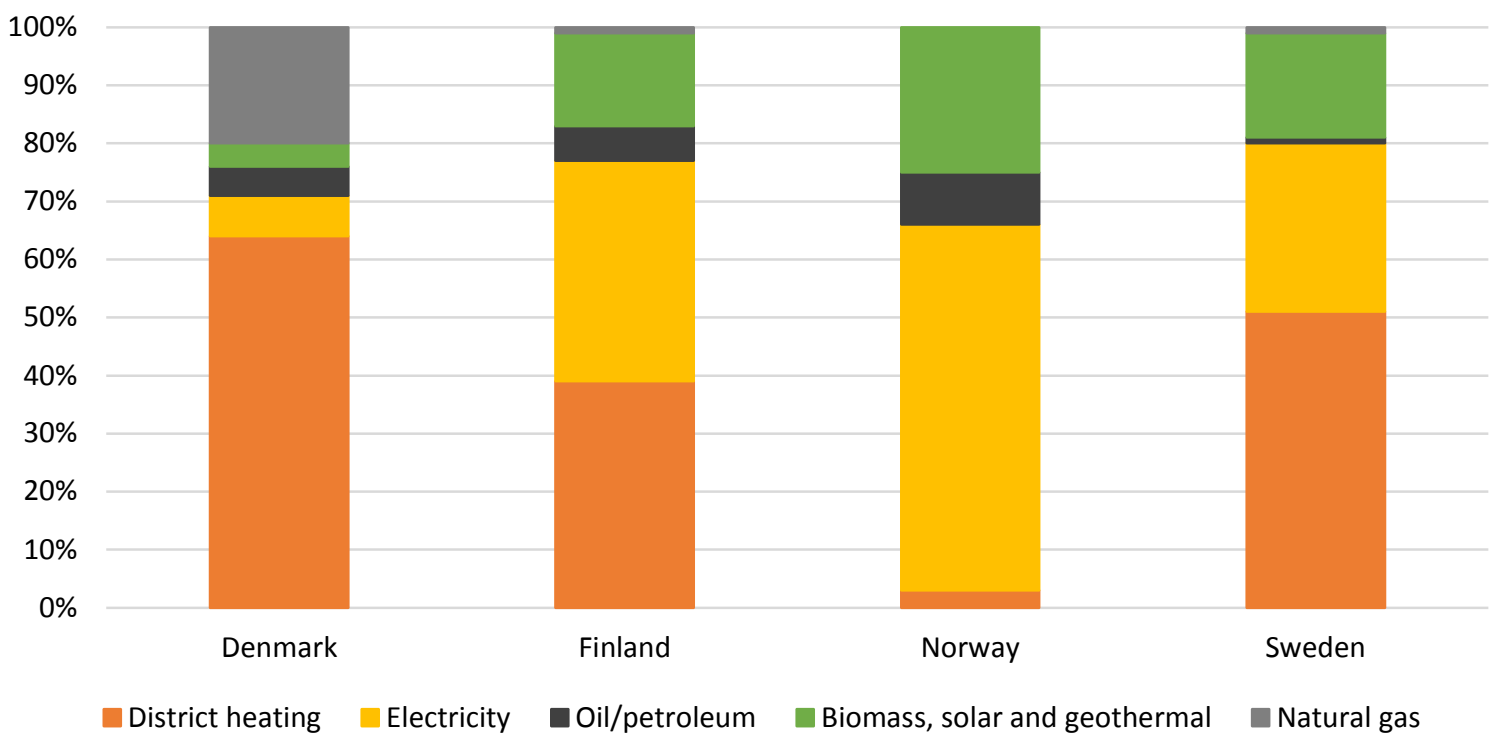

Figure 3: Energy sources used to satisfy Nordic residential heat demand 2015. Sources: [148][149][150][151]

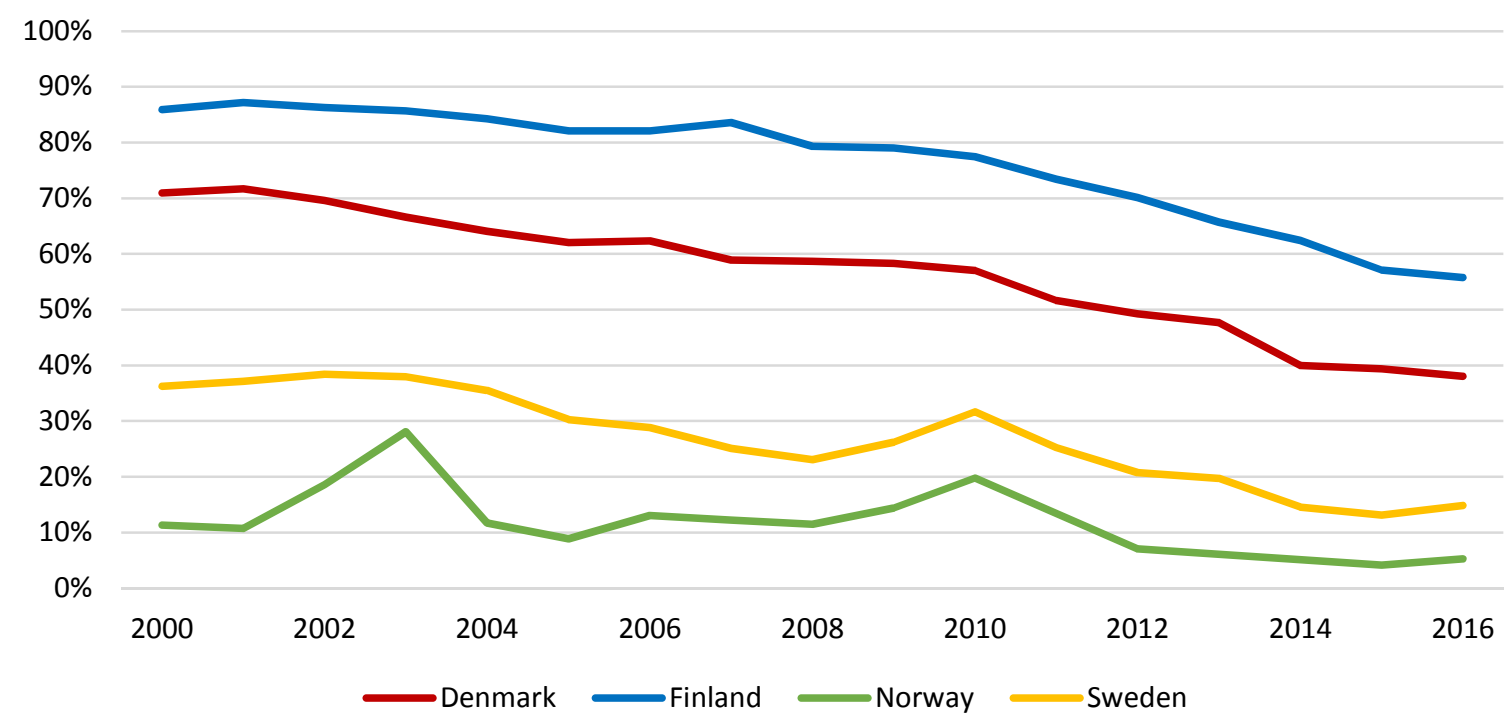

Figure 4: The fossil share of fuels used for Nordic district heat production 2000-2016. Sources:[58][146][152][61][59] 


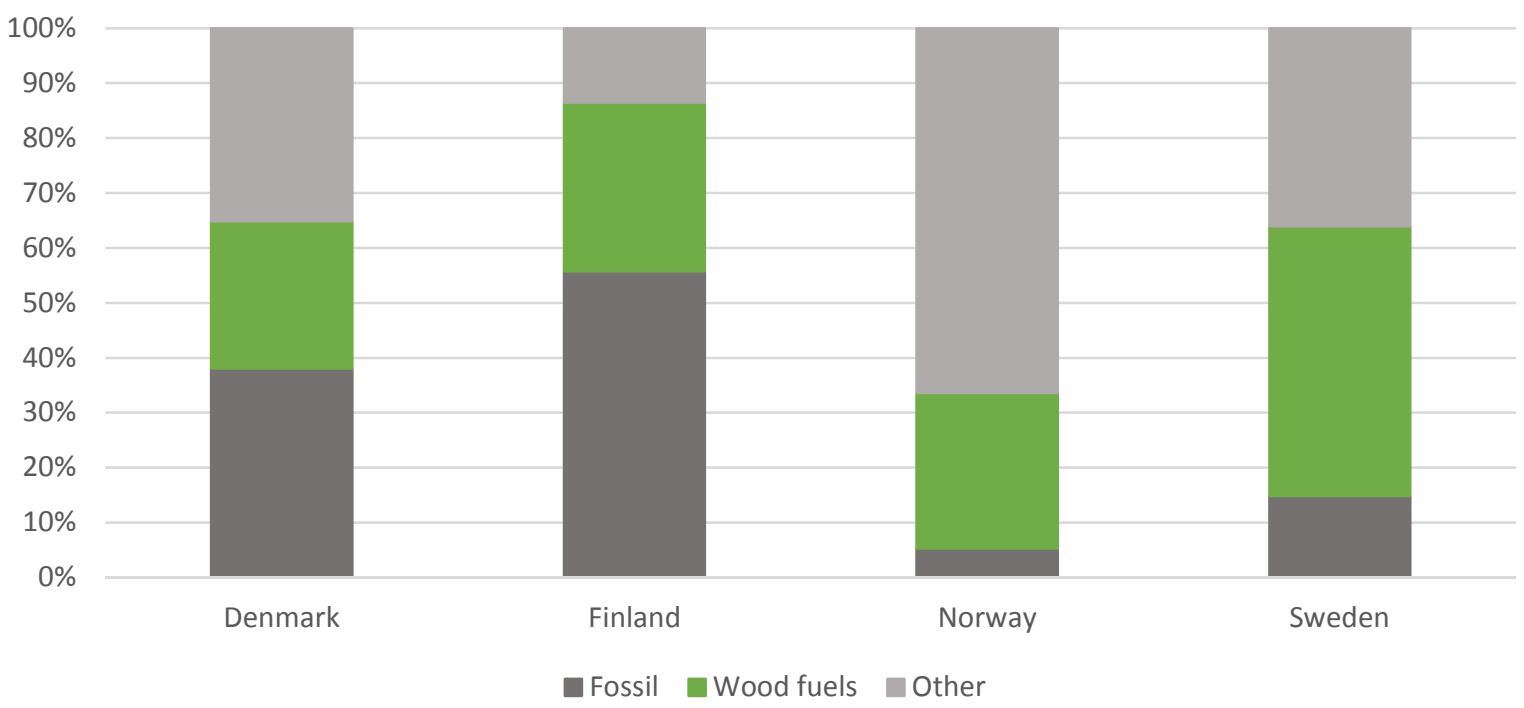

Figure 5: Fuel composition 2016. Sources: [58][146][61][59]

25

20

15

10

5

0
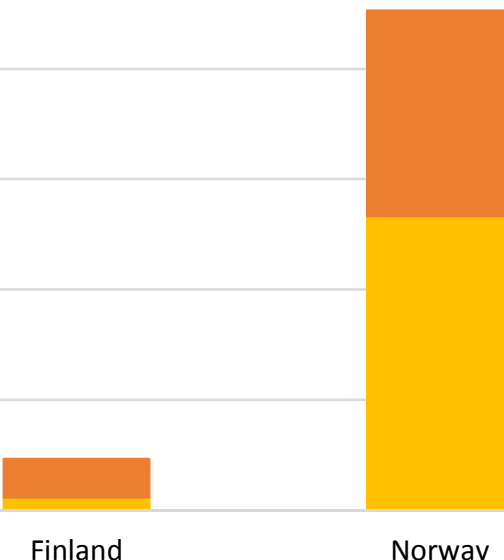

Electric boilers Heat pumps

Figure 6: Share of delivered heat from power to heat technologies in district heating in the Nordic countries. Sources: [153][154][155][59] 


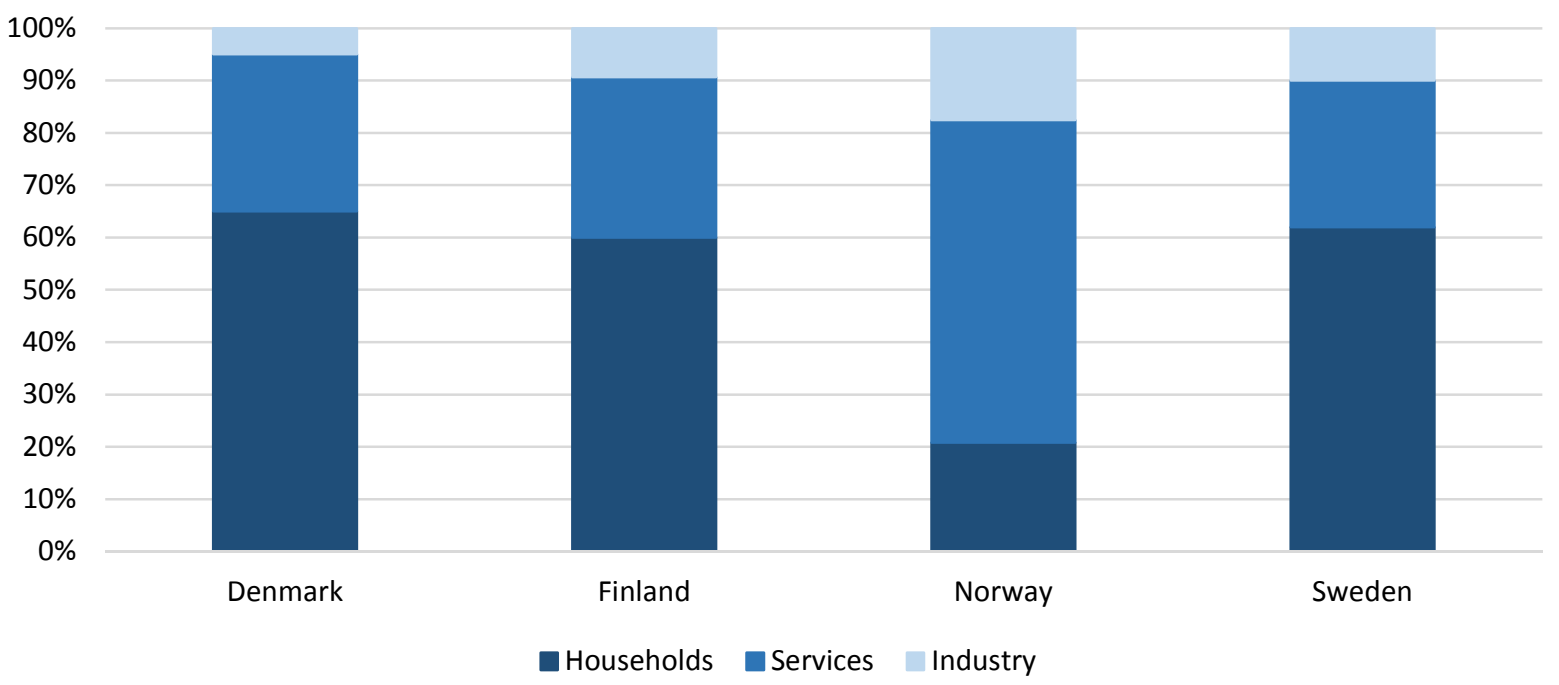

Figure 7: Consumer distribution of Nordic district heat 2015. Sources: [58][154][2][156]

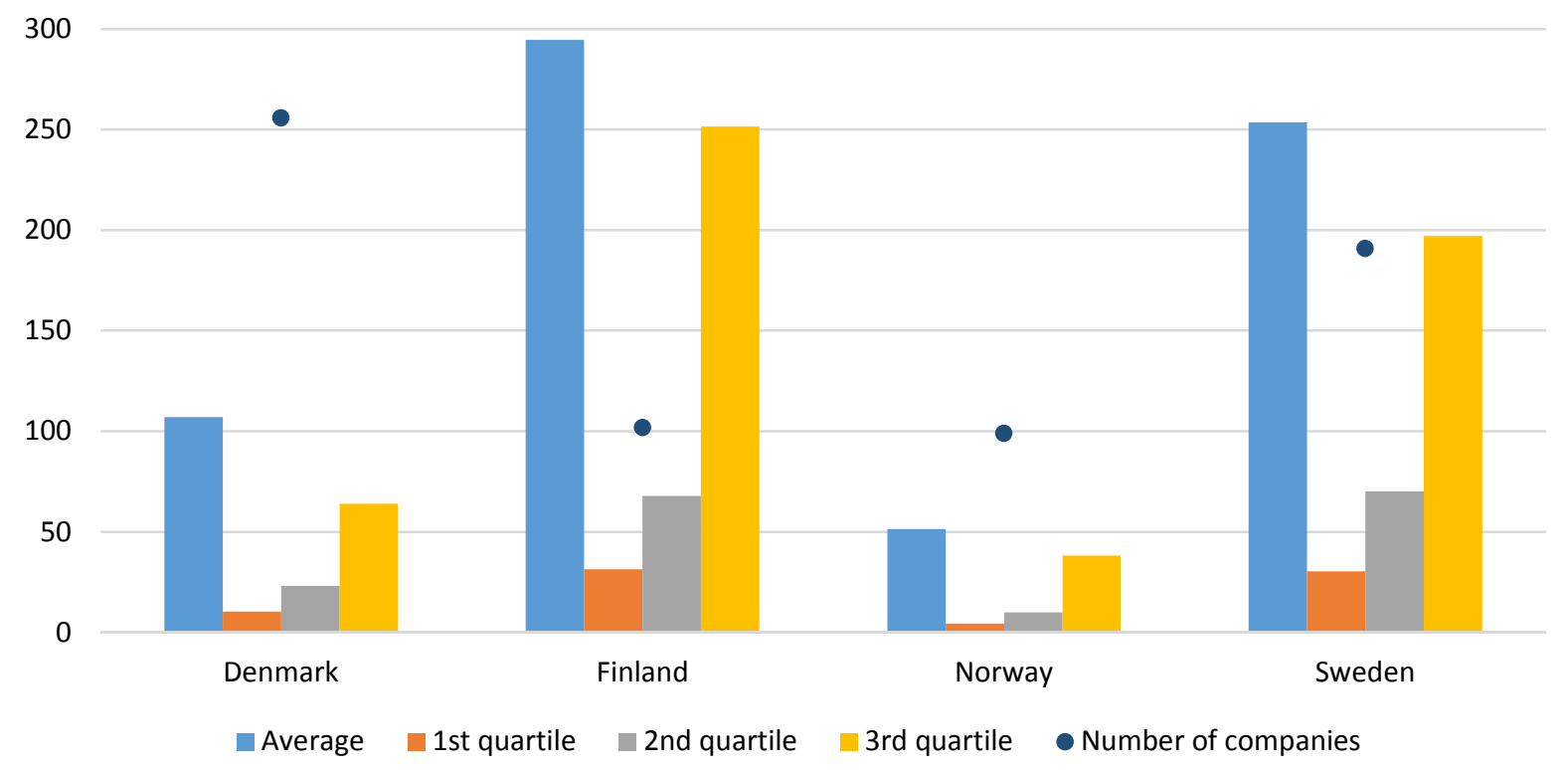

Figure 8: Production levels per company in Nordic district heating 2015. The 4 th quartile is not included, due to anonymity requirements. Sources: [153][154][157][158] 
70

60

50

40

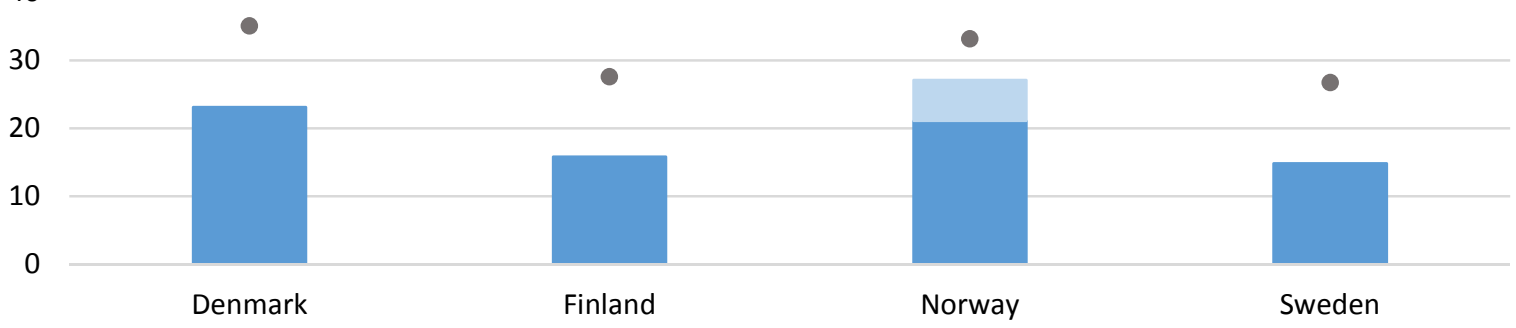

Net profit of heating central (pre tax) Investment subsidy - Operational profit $\diamond$ Gross revenue

Figure 9: Profitability of the model plant

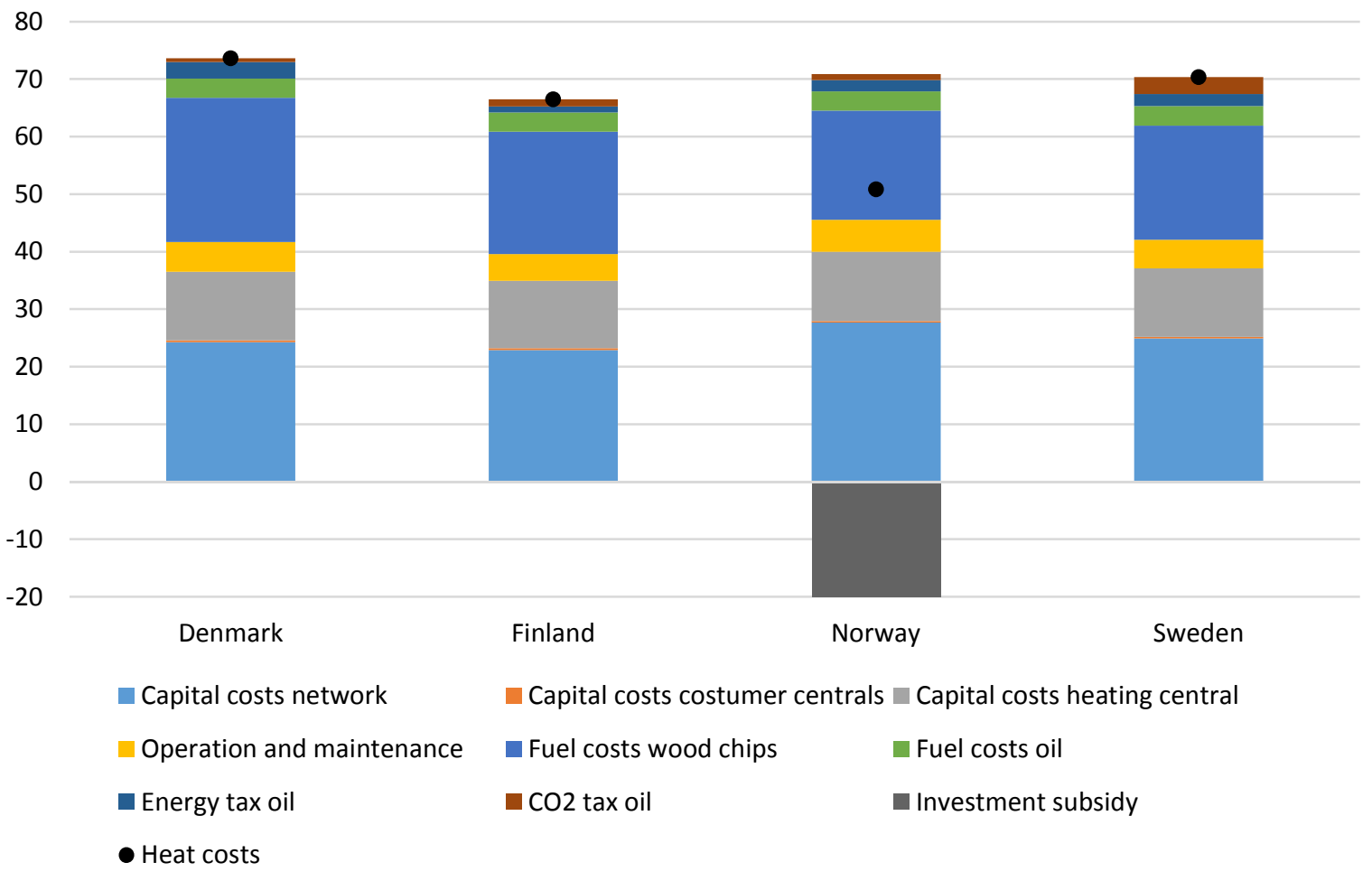


Figure 10: Annual cost components for the model plant

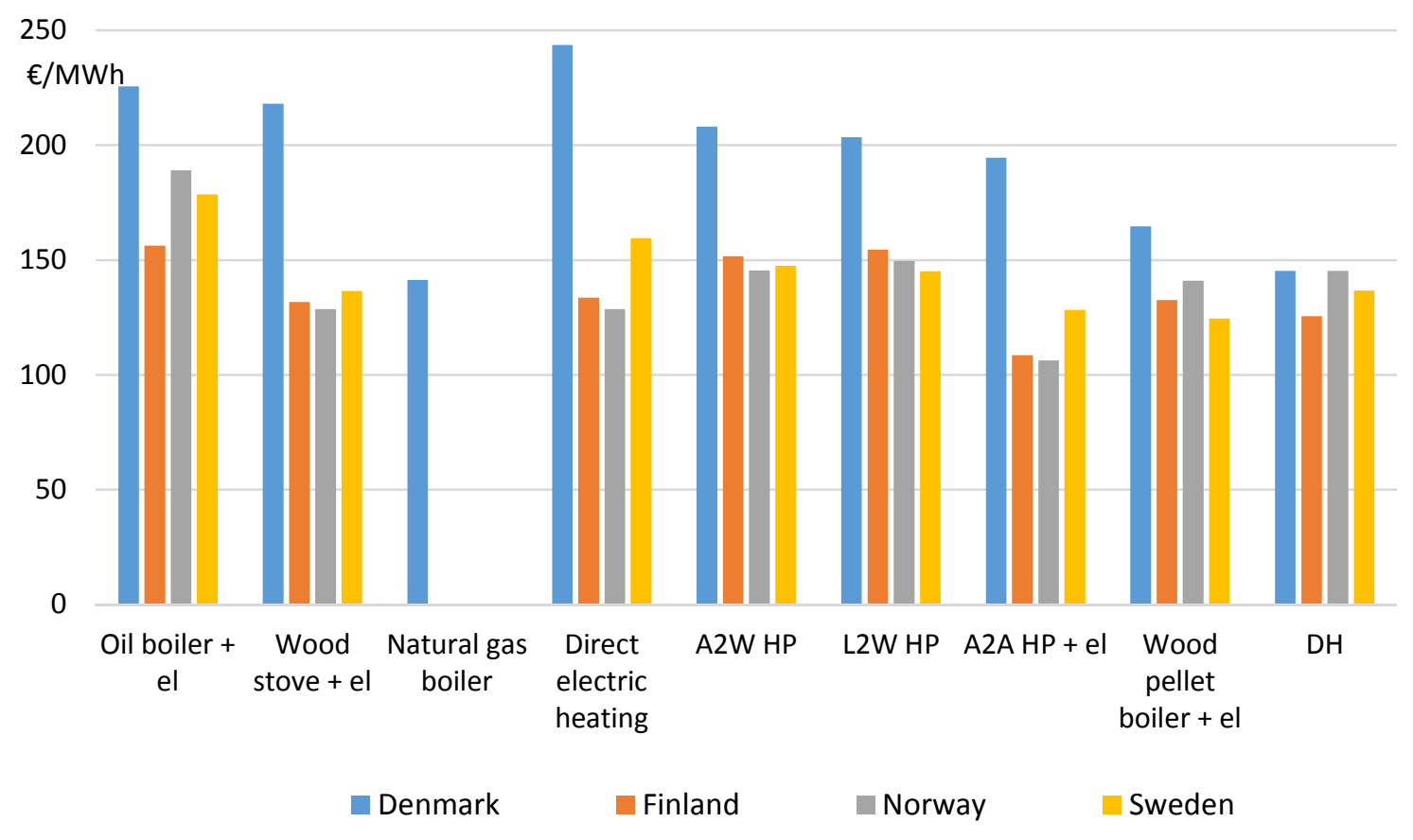

Figure 11: Calculated heating costs in the Nordic countries 2016 
Highlights

- Study of current and former framework conditions in Nordic DH

- Project the likely future development of Nordic DH

- Local commitment and existent infrastructure are the main drivers for DH penetration

- Differences in fuel prices, tax and subsidy schemes affect the fuel composition

- The future of Nordic $\mathrm{DH}$ relies on $\mathrm{CO}_{2}$ prices, electricity prices and energy policy 